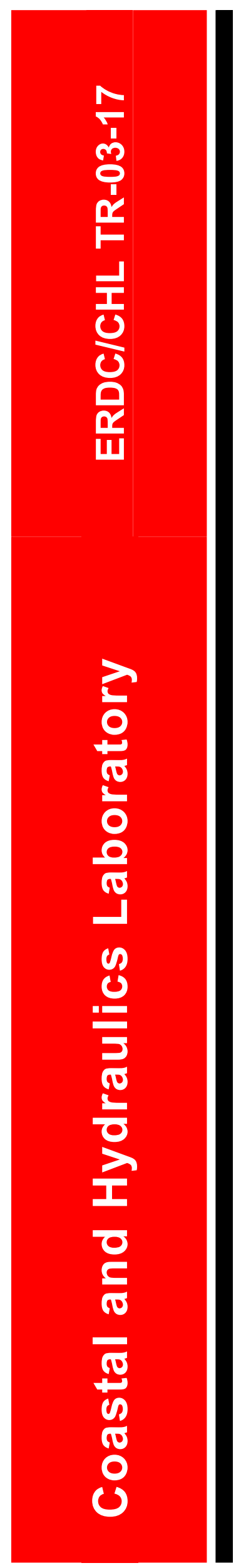

\title{
Upper Guadalupe River Flood Control Weir, San Jose, California
}

Billy D. Fuller

November 2003 


\section{Upper Guadalupe River Flood Control Weir, San Jose, California}

Billy D. Fuller

Coastal and Hydraulics Laboratory

U.S. Army Engineer Research and Development Center

3909 Halls Ferry Road

Vicksburg, MS 39180-6199

Final report

Approved for public release; distribution is unlimited

Prepared for U.S. Army Engineer District, San Francisco

San Francisco, CA 94105-2197 
ABSTRACT: Tests were conducted on a 1:36 scale model of a portion of the Guadalupe River. The study was designed to investigate the design of a control weir located at the upstream end of a bypass channel. The bypass channel was designed to pass excess flow and prevent flooding for river flows up to a 100-year event. The original weir design was modified to achieve desired flow distribution and control.

DISCLAIMER: The contents of this report are not to be used for advertising, publication, or promotional purposes. Citation of trade names does not constitute an official endorsement or approval of the use of such commercial products. All product names and trademarks cited are the property of their respective owners. The findings of this report are not to be construed as an official Department of the Army position unless so designated by other authorized documents. 


\section{Contents}

Conversion Factors, Non-SI to SI Units of Measurement.................................. vi

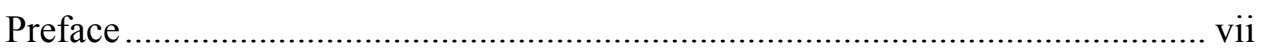

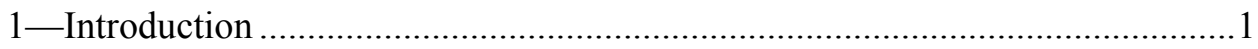

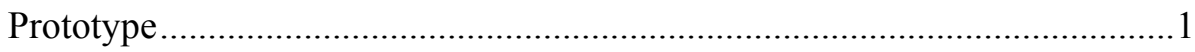

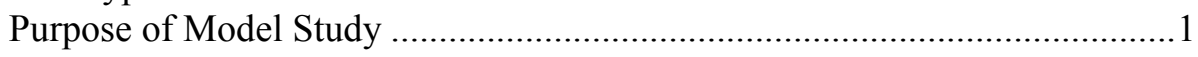

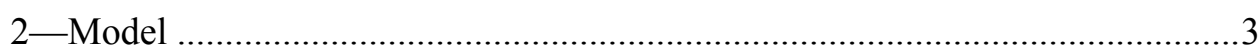

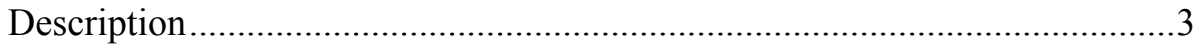

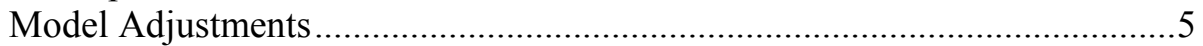

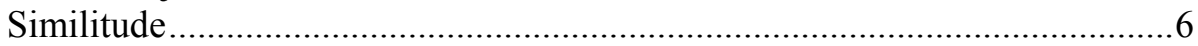

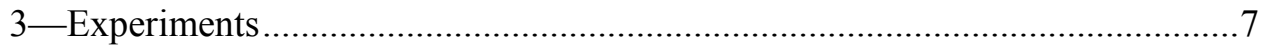

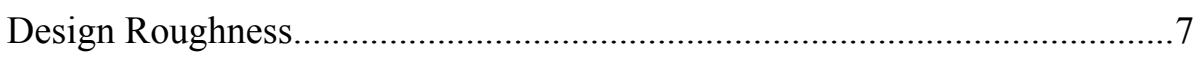

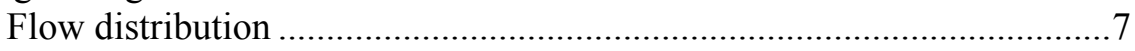

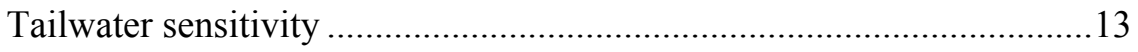

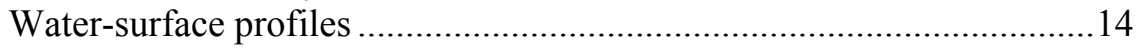

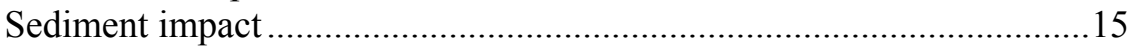

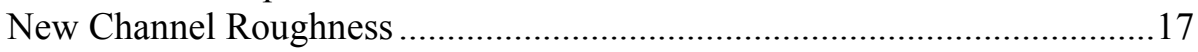

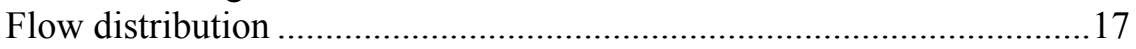

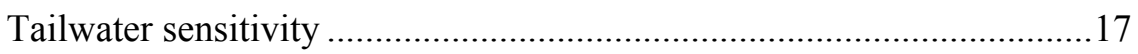

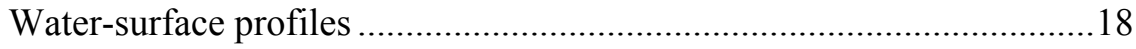

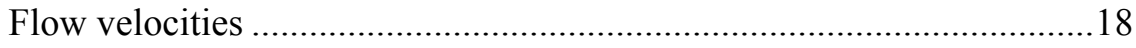

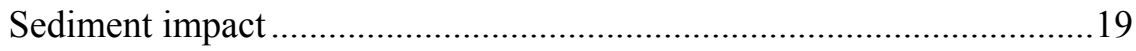

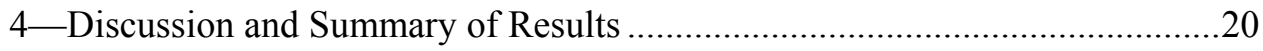

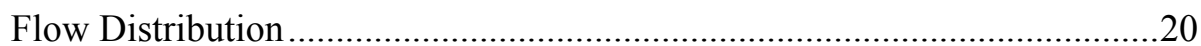

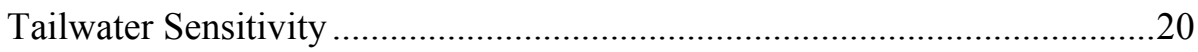

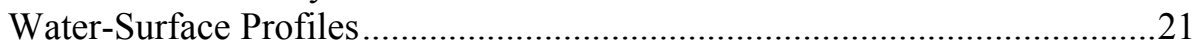

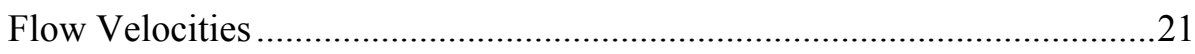

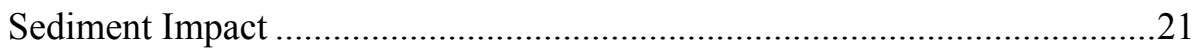

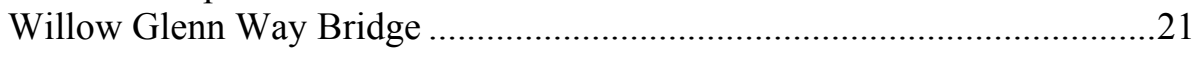

5-Conclusions and Recommendations..........................................................23

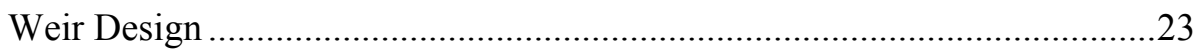

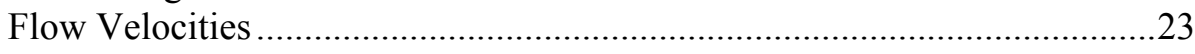

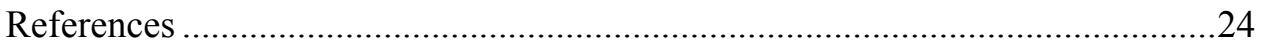

Plates 1-16 
Appendix A - Weir Coefficient Calculations ……...........................................

Appendix B - Water-Surface Profiles, Design Roughness ................................ B1

Appendix C - Water-Surface Profiles, New Channel Roughness........................ 1

SF 298

\section{List of Figures}

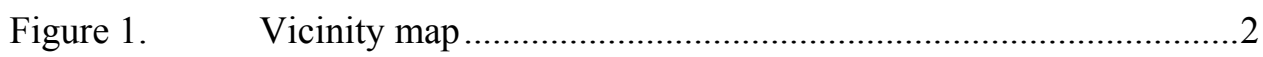

Figure 2. Upper Guadalupe model layout.................................................

Figure 3. Schematic of tailgate and weir ..................................................

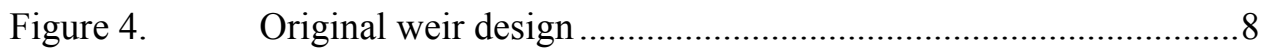

Figure 5. Modified weir design ......................................................... 10

Figure 6. Alternative "final" weir design...............................................11

Figure 7. Sediment deposition design roughness....................................15

Figure 8. Velocity measurement locations ............................................19

Figure 9. Sediment deposition new channel roughness ............................19

Figure 10. Upper Guadalupe bridge pier center-line location

Willow Glen Way.................................................................22

\section{List of Photos}

Photo 1. Original weir looking upstream................................................

Photo 2. Original weir looking downstream ........................................... 9

Photo 3. Final weir looking upstream..................................................... 12

Photo 4. Final weir looking downstream .............................................. 12

Photo 5. Final weir looking downstream...............................................13 


\section{List of Tables}

Table 1. Channel Manning's n Values .........................................................5

Table 2. Scale Relations ....................................................................6

Table 3. Flow Distributions for Design Roughness ...............................13

Table 4. Resulting Flow Distribution for Design Roughness...................14

Table 5. Water-Surface Elevations for Design Roughness .....................14

Table 6. $\quad$ Flow Distribution for Design Roughness with and

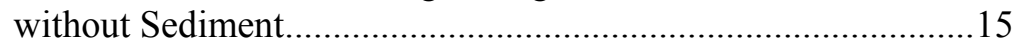

Table 7. Water-Surface Elevations for Design Roughness with Sediment Deposition ............................................................16

Table 8. Water-Surface Elevations Differences for Design Roughness with Sediment Added..............................................16

Table 9. Flow Distributions for New Channel Roughness .......................17

Table 10. Flow Distribution for New Channel Roughness .......................17

Table 11. Water-Surface Elevations for New Channel Roughness ............18

Table 12. Flow Distribution for New Channel Roughness with and

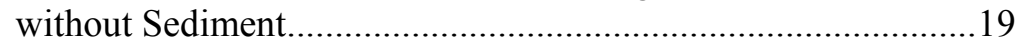

Table 13. Willow Glen Way Bridge Freeboard, 100-Year Event, with and without Debris on Pier..............................................22 


\section{Conversion Factors, Non-SI to SI Units of Measurement}

Non-SI units of measurement used in this report can be converted to SI units as follows:

\begin{tabular}{||l|l|l||}
\hline \hline Multiply & By & To Obtain \\
\hline \hline feet & 0.3048 & meters \\
\hline cubic feet & 0.02831685 & cubic meters \\
\hline degrees (angle) & 0.01745329 & radians \\
\hline
\end{tabular}




\section{Preface}

The model study reported herein was authorized by the Office, Chief of Engineers, U.S. Army, at the request of the U.S. Army Engineer District, San Francisco. Points of contact from the San Francisco District were Messrs. Carlos R. Hernandez, William R. Firth, and David V. Doak.

The study was conducted during the period July 2000 to March 2002 at the Coastal and Hydraulics Laboratory (CHL) of the U.S. Army Engineer Research and Development Center (ERDC). The study was conducted under the administrative supervision of Mr. Thomas W. Richardson, Director, and Dr. William D. Martin, Deputy Director, respectively, CHL, and under the general supervision of Mr. Charles H. Tate, Acting Chief of the Inland Hydraulic Structures Branch, CHL. The Principal Investigator for the model study was Mr. Billy D. Fuller, assisted by Messrs. Douglas White, Kevin Pigg, and Bill Katzenmeyer, all of CHL. The model was constructed by personnel of the Department of Public Works under the direction of Mr. Cecil Dillon. Messrs. Fuller, White, and Katzenmeyer prepared this report.

COL James R. Rowan, EN, was Commander and Executive Director of ERDC. Dr. James R. Houston was Director. 


\section{Introduction}

\section{Prototype}

The project location is on the Guadalupe River in the vicinity of the Willow Glen community in San Jose, CA. The reach being studied is $1,600 \mathrm{ft}^{1}$ long and extends from 7,100 ft upstream of the Southern Pacific Railroad crossing to about $700 \mathrm{ft}$ upstream of the Willow Glen Way bridge. The proposed floodcontrol project consists of the natural channel, a diversion (bypass) channel, for flood flow and a control structure (weir). The project is proposed and designed by the Santa Clara Valley Water District. A vicinity map is included as Figure 1.

\section{Purpose of Model Study}

The purpose of the model study was to investigate the original weir design and to document the water-surface elevations along the natural and bypass channels for several river flows. The San Francisco District provided the weir design, along with its location and orientation. The intent of the weir design was to restrict flows up to $1,500 \mathrm{cfs}$ to the natural channel and to provide a flow distribution of 5,000 cfs in the natural channel and 9,600 cfs in the bypass channel during the 14,600-cfs, 100 -year event. If the original weir design failed to produce desired results, modification details would be provided to the San Francisco District for review prior to its implementation in the model.

Additional investigations were to measure channel velocities in the vicinity of the weir and the Willow Glen Way bridge, and to identify areas that were likely to experience sediment deposition. These two investigations would provide information for bank and channel protection and would indicate areas that could require significant maintenance.

\footnotetext{
${ }^{1}$ Units of measurement in this report are shown in non-SI units. A table of factors for converting non-SI to SI units of measurement is presented on page vii.
} 


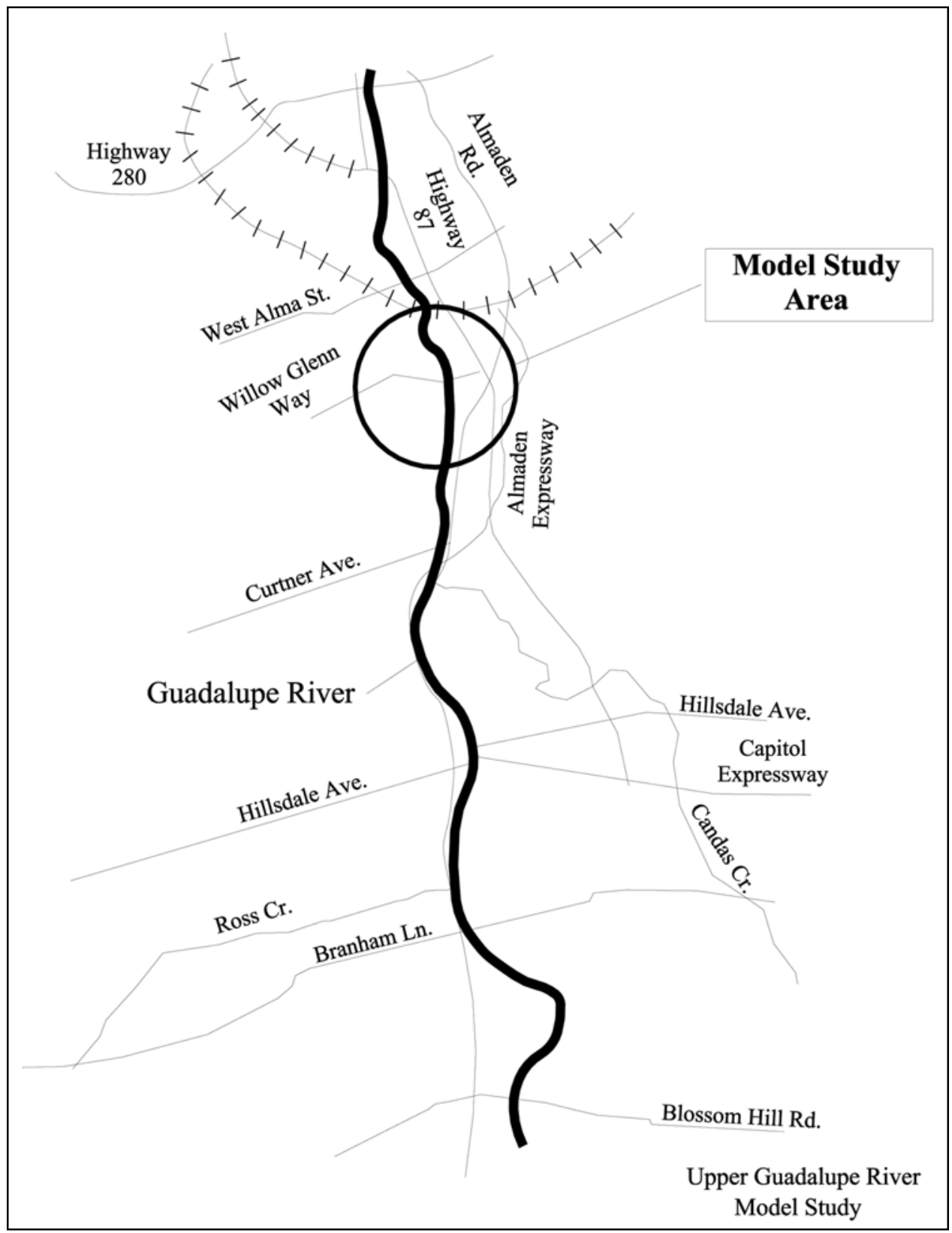

Figure 1. Vicinity map 


\section{Model}

\section{Description}

The 1:30 scale model reproduced the weir and the natural and bypass channels beginning at sta $802+00$ and extending to sta $786+00$ at the downstream extent. The model scale and limits were determined to provide an accurate representation of the flow characteristics necessary to investigate the weir performance. Figure 2 shows the model limits and stationing used in reporting data.

In this model, flow velocities were measured with a pitot tube and discharges were measured with a sharp-crested weir. The limitation of the pitot tube (at this scale) was that velocities of a magnitude less than 2 fps could not be measured. This was not considered a problem in this study because the velocities at which the channel needed protection, as indicated by San Francisco District personnel, were on the order of $20+$ fps.

The model discharge was set by measuring the head over a sharp-crested weir (Figure 3). The head versus discharge was calculated using the method described in King and Brater (1976). This approach was questioned during a mid-study review meeting. As a result, a member of the independent technical review team reviewed the discharge calculations. The discharges calculated from the sharp-crested weirs (one for the natural channel and one for the bypass channel) were determined to be within 5 percent when using calculation procedures from the Water measurement manual (U.S. Department of the Interior 1984), Rouse Engineering Hydraulics (Rouse 1946), and The Handbook of hydraulics (King and Brater 1976) (these calculations are provided in Appendix A). These discharge measurements were within a 10-percent margin of error when scaled to prototype quantities.

Water-surface elevations were measured at the center of the channel on 100$\mathrm{ft}$ intervals. These measurements were made using piezometer taps in the model and point gages over a stilling well for each location. The stilling well dampened the high-frequency changes in water-surface elevation. These measurements were considered average water-surface elevations in subcritical areas of the model. The measurements were average, center of channel water-surface elevations for areas that were supercritical (near the Willow Glen Way bridge and near the control weir at the upstream end of the bypass channel). 


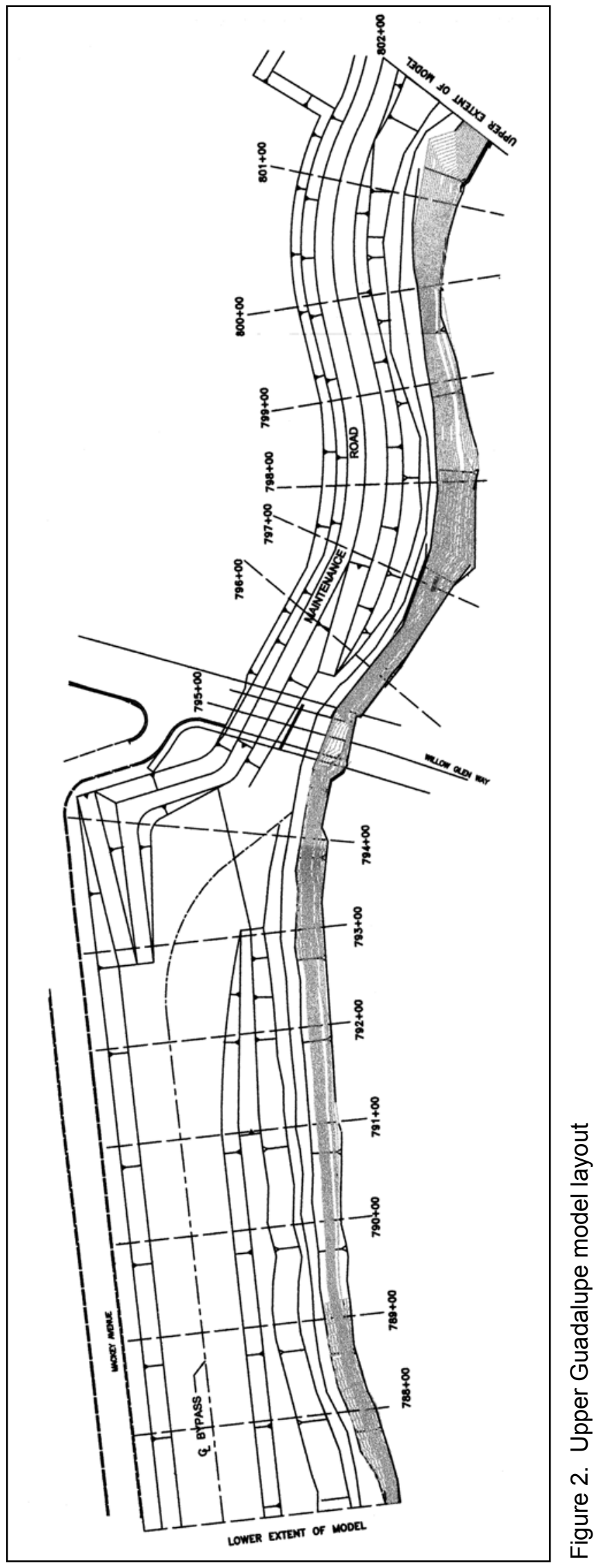




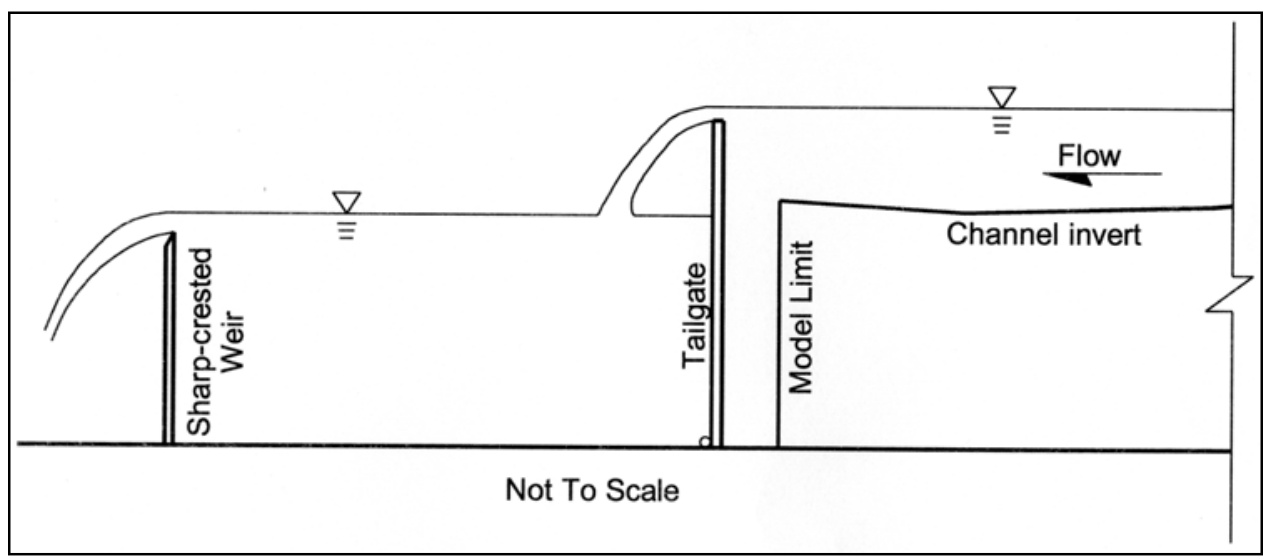

Figure 3. Schematic of tailgate and weir

\section{Model Adjustments}

To insure the model provided realistic information, the investigation was set up to document flow conditions for two channel roughnesses: a design roughness and a new channel roughness. These two roughnesses would represent a channel condition some years in the future and a channel condition shortly after construction, respectively. The design roughness was considered to provide conservative water-surface elevations and flow distributions and was therefore used to evaluate the performance and necessary design changes for the weir. The new channel roughness was investigated to demonstrate the sensitivity of the weir to channel roughness and to document conservative velocities for use in designing channel protection.

The San Francisco District provided water-surface profiles representing the two channel roughnesses. They were calculated using the HECRAS numerical code. These water-surface profiles were considered to be boundary conditions and the true prototype response would lie in between these conditions.

Table 1 shows the Manning's $n$ value represented by these boundary roughnesses.

\section{Table 1}

Channel Manning's $\mathrm{n}$ Values

\begin{tabular}{||l|l|l||}
\hline \hline & Natural Channel & Bypass Channel \\
\hline \hline Design Roughness & 0.050 & 0.033 \\
\hline New Channel Roughness & 0.040 & 0.028 \\
\hline
\end{tabular}

The model roughness was initially set for the design roughness $(n=0.050$ in the natural channel and $n=0.033$ in the bypass channel). To achieve the desired roughness, the model discharge was set to 1,500 cfs (lowest event in the study) and the tailwater (from the San Francisco District HECRAS study corresponding to the design roughness and 1,500 cfs discharge) was set (Figure 3). Starting at the downstream end of the channels, roughness (expanded metal) was added to the wetted portion of the channel. The type of the expanded metal was changed until the water surface matched the San Francisco District water surface. Once 
the 1,500-cfs event roughness was achieved, the model discharge was set to 14,600 cfs (100-year event) and the tailwater (from the San Francisco District HECRAS study corresponding to the design roughness and 14,600 cfs discharge) was set. With the higher flow, the upper portion of the wetted channel required roughness adjustment. Wire mesh was used to provide enough roughness to the channel to match the water surfaces. The new channel roughness was set in the same manner.

\section{Similitude}

The accepted equations of hydraulic similitude, based on the Froudian criteria, were used to express the mathematical relations between the dimensions and hydraulic quantities of the model and the prototype. A model scale was selected that would provide a model Reynolds number high enough to overcome viscous forces in the model. The general relations expressed in terms of the model's scale or length ratio, $\mathrm{L}_{\mathrm{r}}$, are expressed in Table 2 .

\begin{tabular}{|c|c|c|}
\hline Dimension & Ratio & Scale Relation \\
\hline Length & $\overline{\mathrm{L}_{\mathrm{r}}}$ & $1: 30$ \\
\hline Area & $\mathrm{A}_{\mathrm{r}}=\mathrm{L}_{\mathrm{r}}^{2}$ & $1: 900$ \\
\hline Velocity & $V_{r}=L_{r}^{1 / 2}$ & $1: 5.477$ \\
\hline Discharge & $Q_{r}=L_{r}^{5 / 2}$ & $1: 4929$ \\
\hline Time & $\mathrm{T}_{\mathrm{r}}=\mathrm{L}_{\mathrm{r}}^{1 / 2}$ & $1: 5.477$ \\
\hline Force & $F_{r}=L_{r}^{3}$ & $1: 27,000$ \\
\hline Frequency & $f_{r}=1 / L_{r}^{1 / 2}$ & $1: 0.183$ \\
\hline
\end{tabular}

Measurements of each of the dimensions or variables can be transferred qualitatively from model to prototype equivalents by means of the scale relations in Table 2. All model data are presented in terms of prototype equivalents. 


\section{Experiments}

\section{Design Roughness}

\section{Flow distribution}

The weir had to produce two design distributions. Up to $1,500 \mathrm{cfs}$ of all the flow was to remain in the natural channel with no bypass flow. For the 100-year event, 5,000 cfs was to flow in the natural channel and 9,600 cfs in the bypass channel. To meet the first requirement of $1,500 \mathrm{cfs}$ in the natural channel prior to utilizing the bypass, the original weir (Figure 4; Photos 1 and 2) had to be modified by raising the top elevation by $1.25 \mathrm{ft}$. The second requirement was achieved by reducing the weir length to $128 \mathrm{ft}$ (Figure 5). An alternative weir representing these dimensions and incorporating more aesthetic features was installed in the model (Figure 6; Photos 3-5). This weir was constructed of acrylic plastic and became the final recommended weir design based upon model test results.

After the weir dimensions had been modified to provide desirable flow distributions at the two target discharges (1.2-year event and the 100-year event), flow distributions were measured for intermediate events as shown in Table 3. 


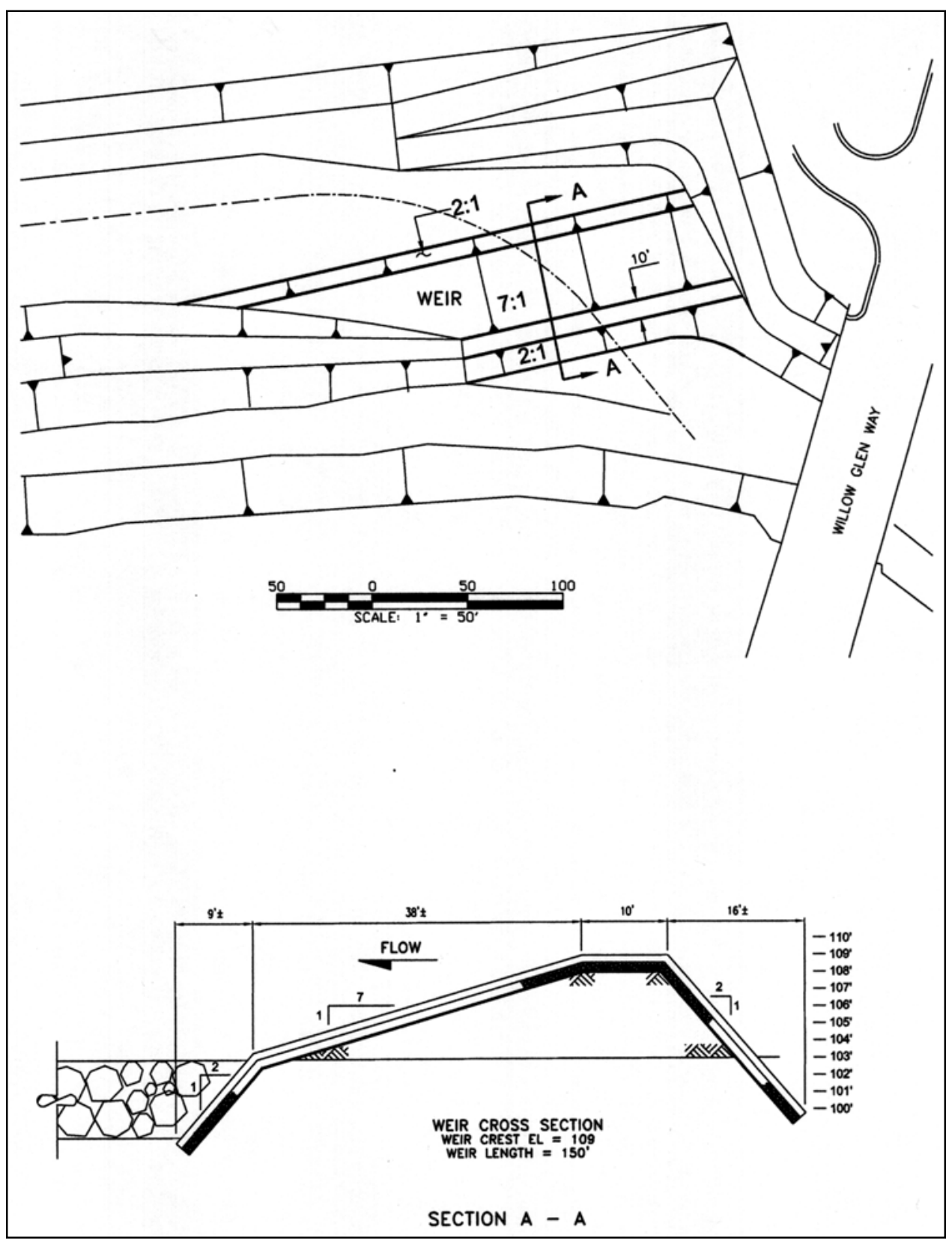

Figure 4. Original weir design 


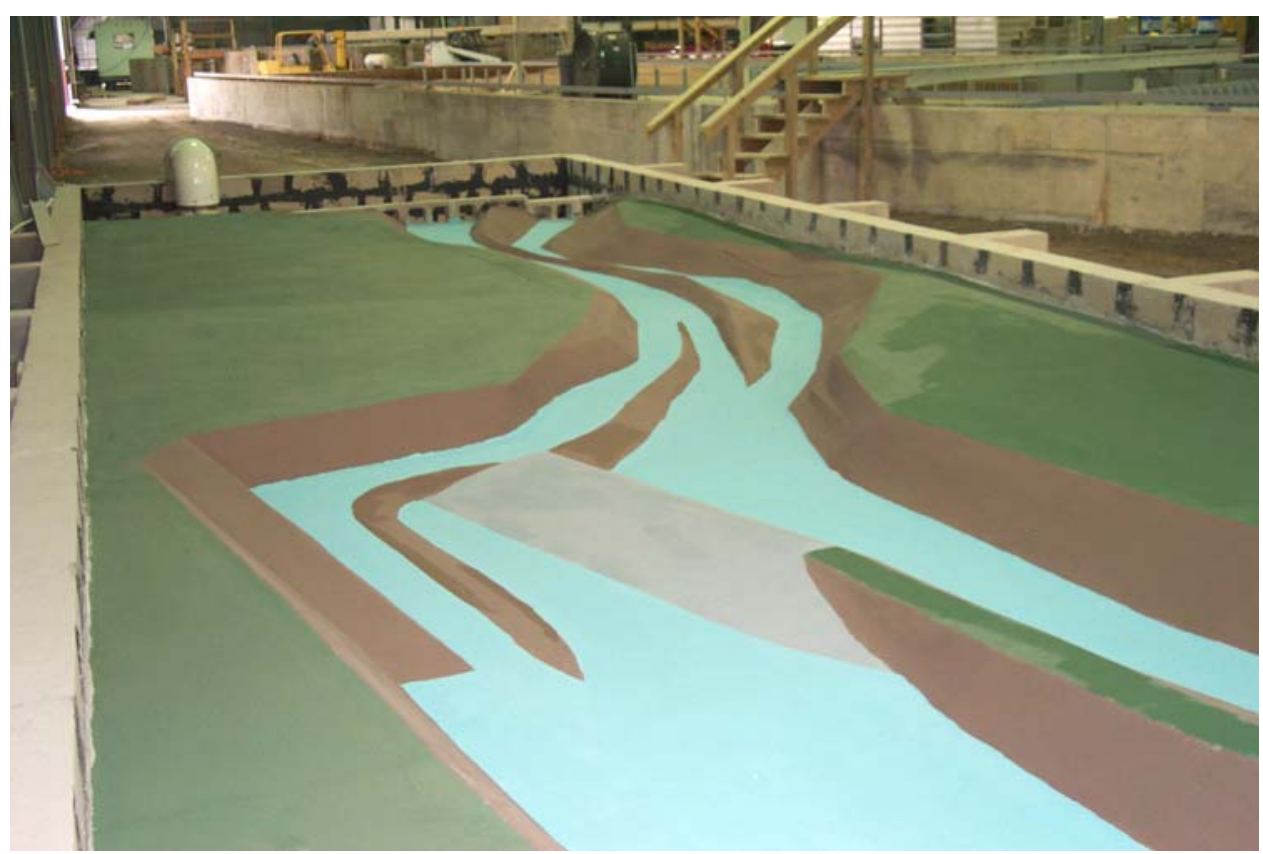

Photo 1. Original weir looking upstream

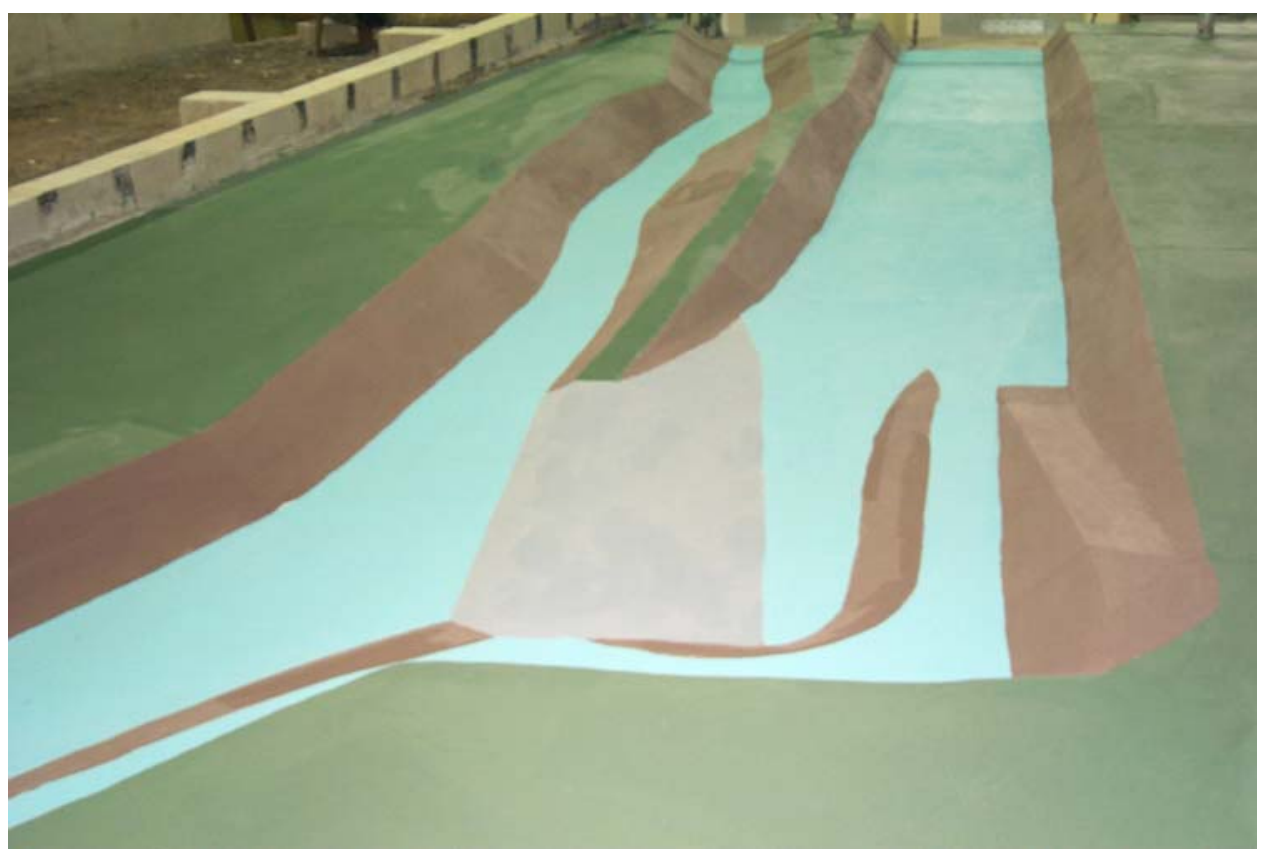

Photo 2. Original weir looking downstream 


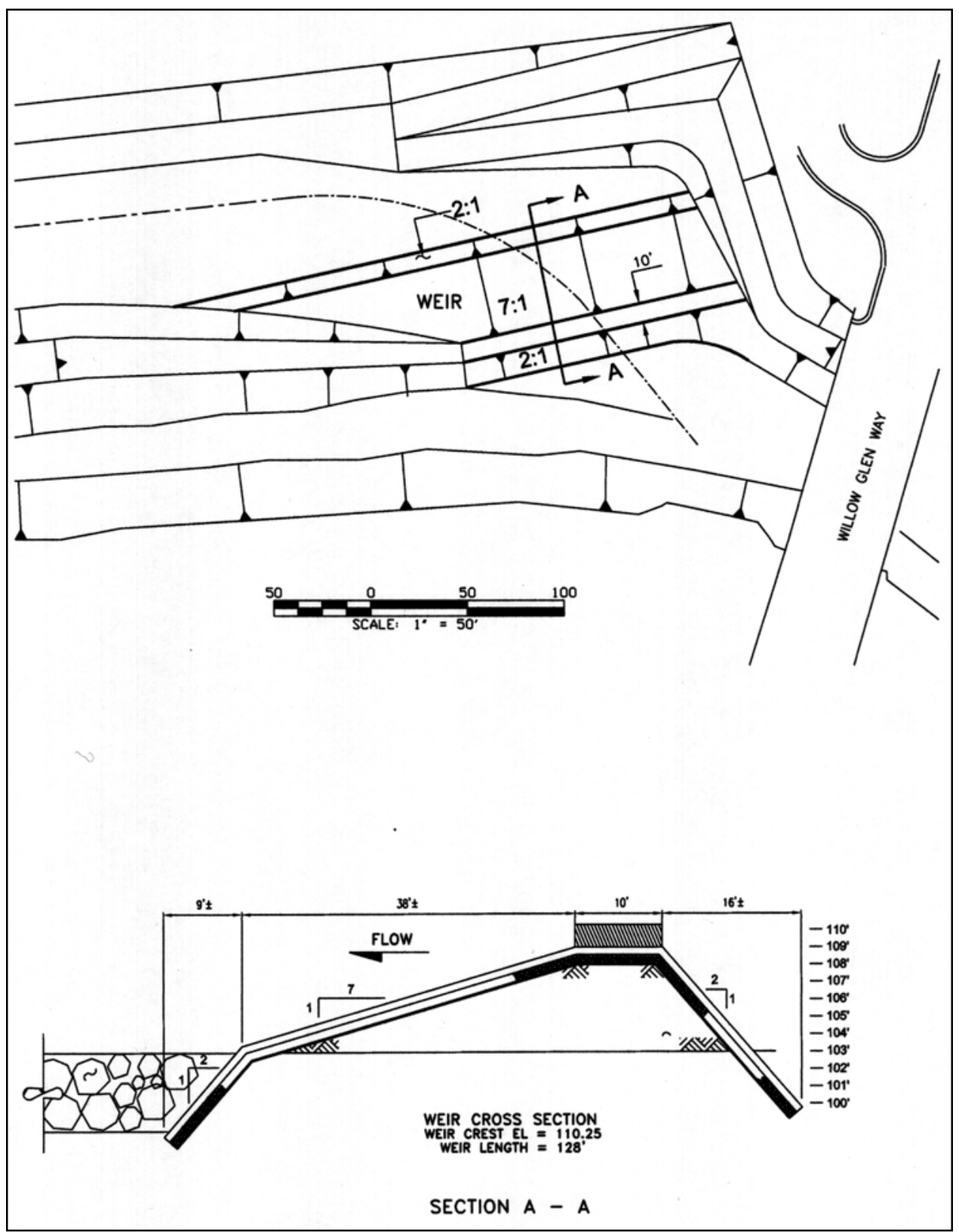

Figure 5. Modified weir design 


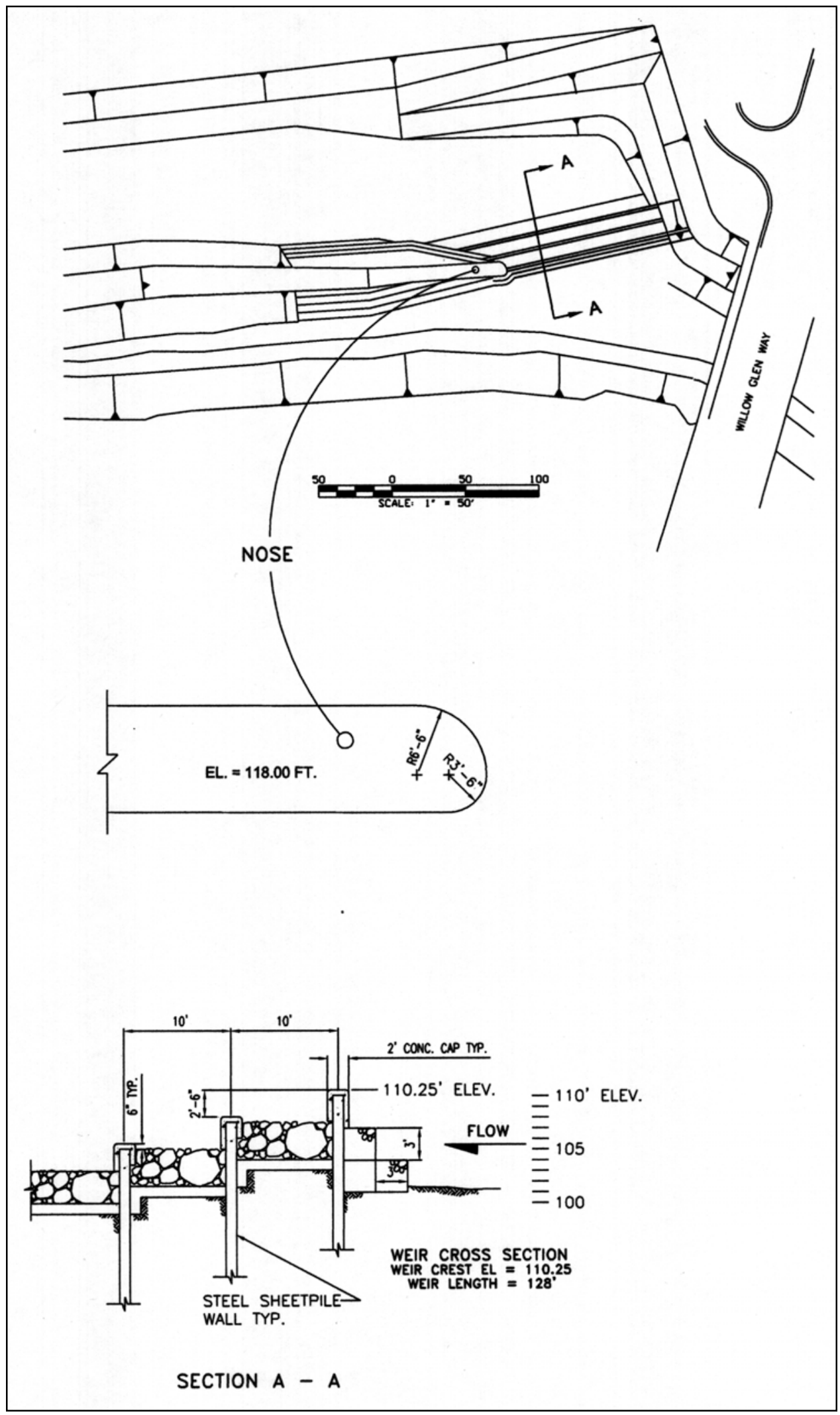

Figure 6. Alternative "final" weir design 


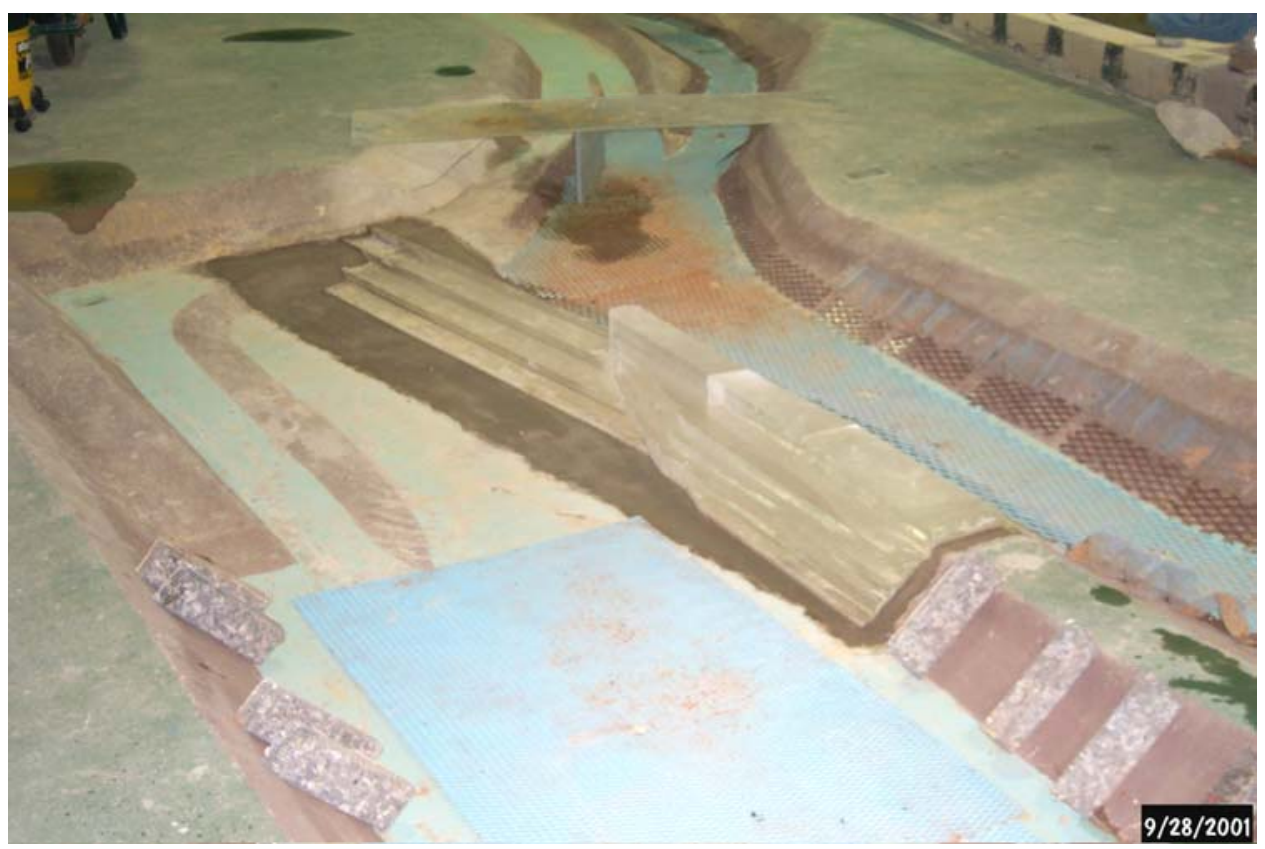

Photo 3. Final weir looking upstream

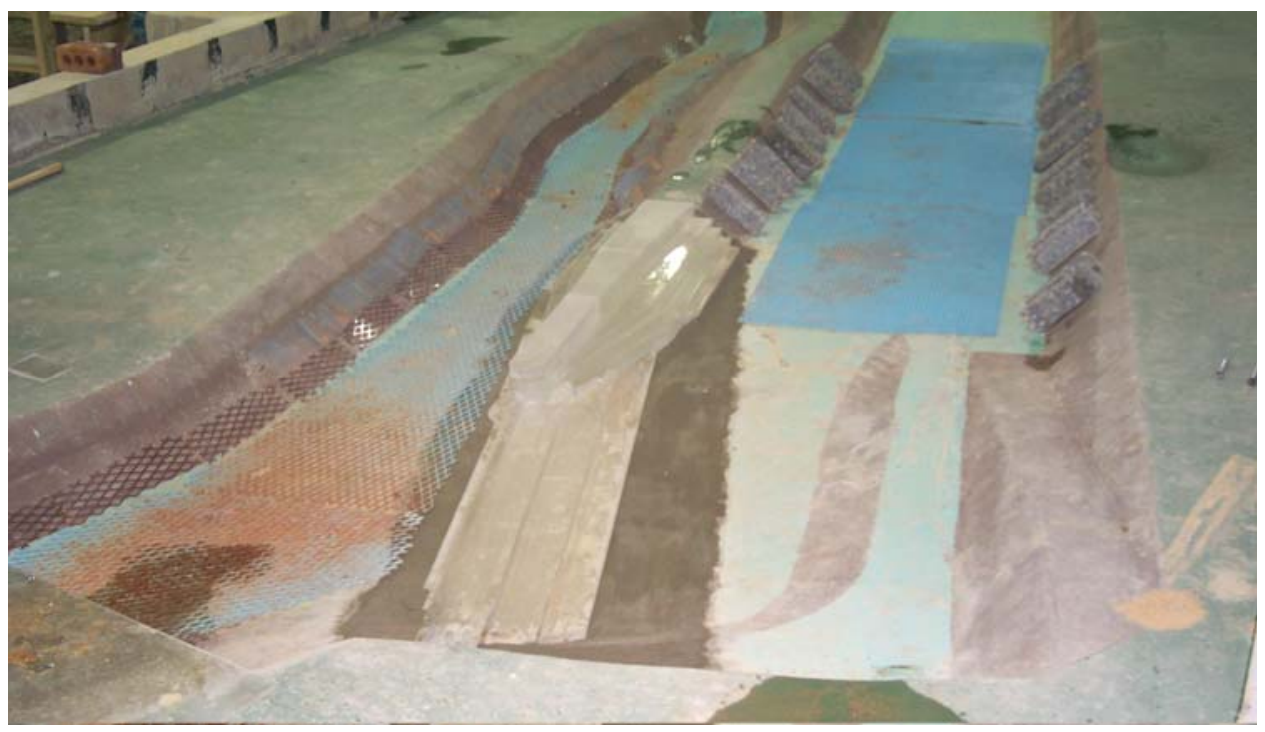

Photo 4. Final weir looking downstream from right bank 


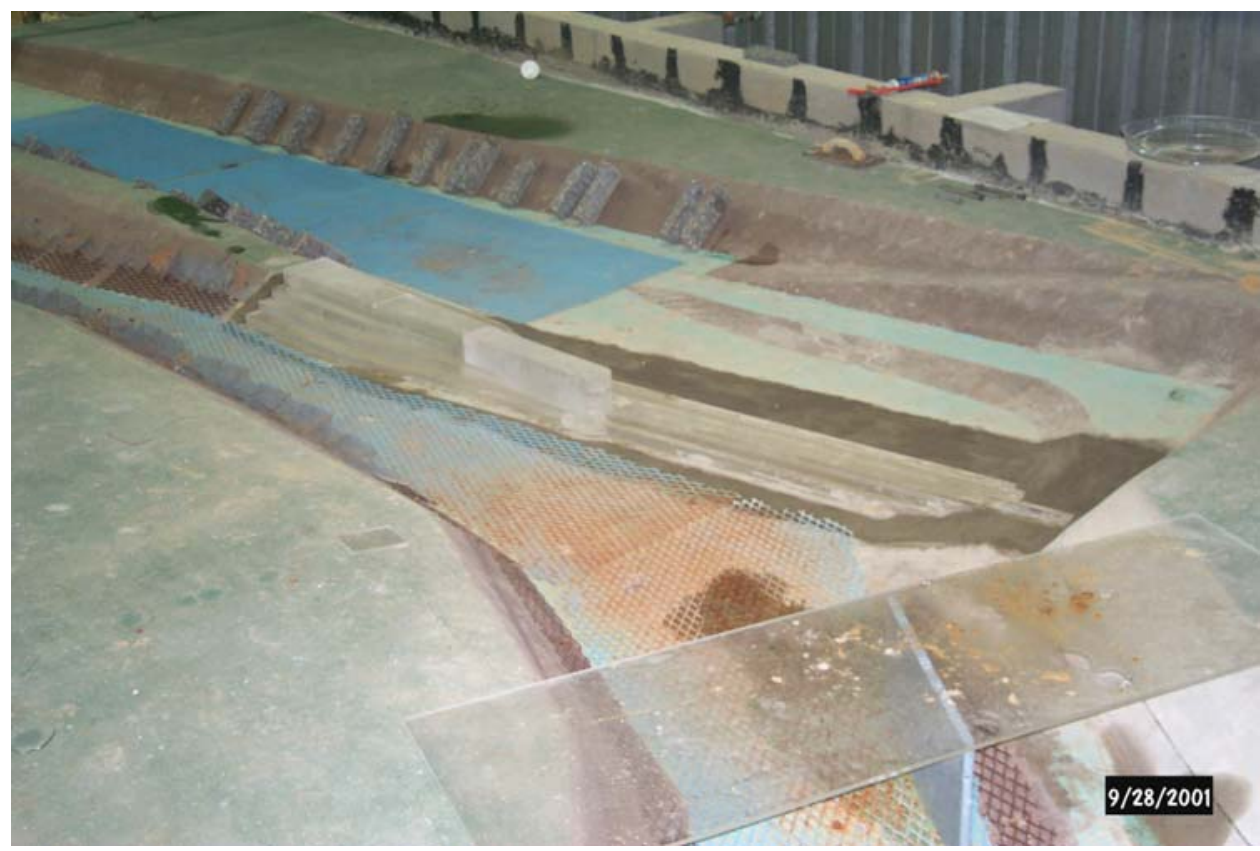

Photo 5. Final weir looking downstream from left bank

\begin{tabular}{|c|c|c|c|}
\hline \multicolumn{4}{|c|}{$\begin{array}{l}\text { Table } 3 \\
\text { Flow Distributions for Design Roughness }\end{array}$} \\
\hline Event & $\begin{array}{l}\text { Discharge, } \\
\text { cfs }\end{array}$ & $\begin{array}{l}\text { Natural Channel Discharge, } \\
\text { cfs }\end{array}$ & $\begin{array}{l}\text { Bypass Channel Discharge, } \\
\text { cfs }\end{array}$ \\
\hline 1.2-year & 1,500 & 1,500 & 0 \\
\hline 10 -year & 7,100 & 3,350 & 3,750 \\
\hline 20-year & 9,000 & 3,800 & 5,200 \\
\hline 100-year & 14,600 & 5,000 & 9,600 \\
\hline
\end{tabular}

\section{Tailwater sensitivity}

The sensitivity of the flow distributions to tailwater elevation was determined for the discharge and tailwater elevation adjustment values shown in Table 4. The tailwater elevation in each channel (natural and bypass) was increased or decreased simultaneously by the amount indicated in the table. The table also indicates the flow distribution changes for the associated change in tailwater elevation. With the exception of the 1,500-cfs flow, higher tailwater elevations caused more flow to enter the bypass channel. 


\begin{tabular}{|c|c|c|c|c|}
\hline \multicolumn{5}{|c|}{$\begin{array}{l}\text { Table } 4 \\
\text { Resulting Flow Distribution for Design Roughness }\end{array}$} \\
\hline Event & $\begin{array}{l}\text { Discharge, } \\
\text { cfs }\end{array}$ & $\begin{array}{l}\text { Natural Channel } \\
\text { Discharge, cfs }\end{array}$ & $\begin{array}{l}\text { Bypass Channel } \\
\text { Discharge, cfs }\end{array}$ & Tailwater \\
\hline \multirow[t]{4}{*}{ 1.2-year } & \multirow[t]{4}{*}{$\bar{~} 1,500$} & 1,500 & 0 & $-1.0-\mathrm{ft}$ \\
\hline & & 1,500 & 0 & Design \\
\hline & & 1,500 & 0 & $+1.0-\mathrm{ft}$ \\
\hline & & 1,300 & 200 & $+2.0-\mathrm{ft}$ \\
\hline \multirow[t]{4}{*}{ 10-year } & \multirow[t]{4}{*}{7,100} & 3,450 & 3,650 & $-1.0-\mathrm{ft}$ \\
\hline & & 3,350 & 3,750 & Design \\
\hline & & 3,250 & 3,850 & $+1.0-\mathrm{ft}$ \\
\hline & & 2,750 & 4,350 & $+2.0-\mathrm{ft}$ \\
\hline \multirow[t]{4}{*}{ 20-year } & \multirow[t]{4}{*}{9,000} & 3,900 & 5,100 & $-1.0-\mathrm{ft}$ \\
\hline & & 3,800 & 5,200 & Design \\
\hline & & 3,450 & 5,550 & $+1.0-\mathrm{ft}$ \\
\hline & & 2,950 & 6,050 & $+2.0-\mathrm{ft}$ \\
\hline \multirow[t]{4}{*}{ 100-year } & \multirow[t]{4}{*}{14,600} & 5,000 & 9,600 & $-1.0-\mathrm{ft}$ \\
\hline & & 5,000 & 9,600 & Design \\
\hline & & 5,000 & 9,600 & $+1.0-\mathrm{ft}$ \\
\hline & & 4,600 & 10,000 & $+2.0-\mathrm{ft}$ \\
\hline
\end{tabular}

\section{Water-surface profiles}

Water-surface profiles were documented for the four events with four tailwater elevations. These data are presented in Table 5 and drawings in Appendix B. These values are based on point measurements in the center of the channel. In subcritical flow areas of the model, they are considered to be average water-surface elevations.

\begin{tabular}{|c|c|c|c|c|c|c|c|c|}
\hline \multicolumn{9}{|c|}{$\begin{array}{l}\text { Table } 5 \\
\text { Water-Surface Elevations for Design Roughness }\end{array}$} \\
\hline \multirow[b]{3}{*}{ Station } & \multirow{2}{*}{\multicolumn{4}{|c|}{$\begin{array}{c}\text { Natural Channel Water-Surface Elevation, NGVD } \\
\text { Event }\end{array}$}} & \multicolumn{4}{|c|}{$\begin{array}{l}\text { Bypass Channel Water-surface Elevation, NGVD } \\
\end{array}$} \\
\hline & & & & & \multicolumn{4}{|c|}{ Event } \\
\hline & 1.2-year & 10-year & 20-year & 100-year & 1.2-year & 10-year & 20-year & 100-year \\
\hline $801+00$ & 113.16 & 117.90 & 119.28 & 122.10 & \multirow{14}{*}{$\begin{array}{l}\frac{3}{1} \\
\frac{0}{4} \\
\frac{0}{2}\end{array}$} & & & \\
\hline $800+00$ & 113.19 & 118.14 & 119.43 & 122.07 & & & & \\
\hline $799+00$ & 113.04 & 117.96 & 119.16 & 121.65 & & & & \\
\hline $798+00$ & 112.68 & 117.57 & 118.89 & 121.56 & & & & \\
\hline $797+00$ & 111.90 & 116.49 & 117.78 & 120.36 & & & & \\
\hline $796+00$ & 110.51 & 112.47 & 113.07 & 115.17 & & & & \\
\hline $795+00$ & 110.43 & 112.47 & 112.86 & 114.90 & & & & \\
\hline $794+00$ & 110.34 & 113.28 & 113.58 & 115.44 & & & & \\
\hline $793+00$ & 110.16 & 113.19 & 113.94 & 115.80 & & 109.50 & 111.12 & 114.99 \\
\hline $792+00$ & 109.59 & 112.86 & 113.88 & 116.28 & & 109.53 & 111.18 & 115.05 \\
\hline $791+00$ & 109.08 & 112.05 & 113.22 & 115.62 & & 109.26 & 112.65 & 114.63 \\
\hline $790+00$ & 109.14 & 111.99 & 113.10 & 115.59 & & 109.02 & 110.52 & 114.36 \\
\hline $789+00$ & 108.84 & 111.51 & 112.68 & 115.20 & & 108.96 & 110.49 & 114.18 \\
\hline $788+00$ & 108.55 & 111.24 & 112.50 & 115.17 & & 109.05 & 110.58 & 114.39 \\
\hline
\end{tabular}




\section{Sediment impact}

Sediment was introduced in the model to illustrate areas of likely deposition. The magnitude (quantity) of this deposition is not relative to prototype expectations. The procedure used to introduce the sediment was to set the discharge to the 100-year event (14,600 cfs) and deposit 5,000 cu yd of material in $2 \mathrm{hr}$, let the river flow for $30 \mathrm{~min}$, deposit another 5,000 cu yd at the same rate and then let the river flow for another $30 \mathrm{~min}$. The flow was shut off and the sediment deposits were dusted with cement to allow investigation of sediment effects with several flow conditions. The procedure (as described) and material (sand that simulates about 0.25 in. gravel in the prototype) was the same as that used in Hite (1998). Figure 7 is a plan view of the model showing areas of sediment deposition.

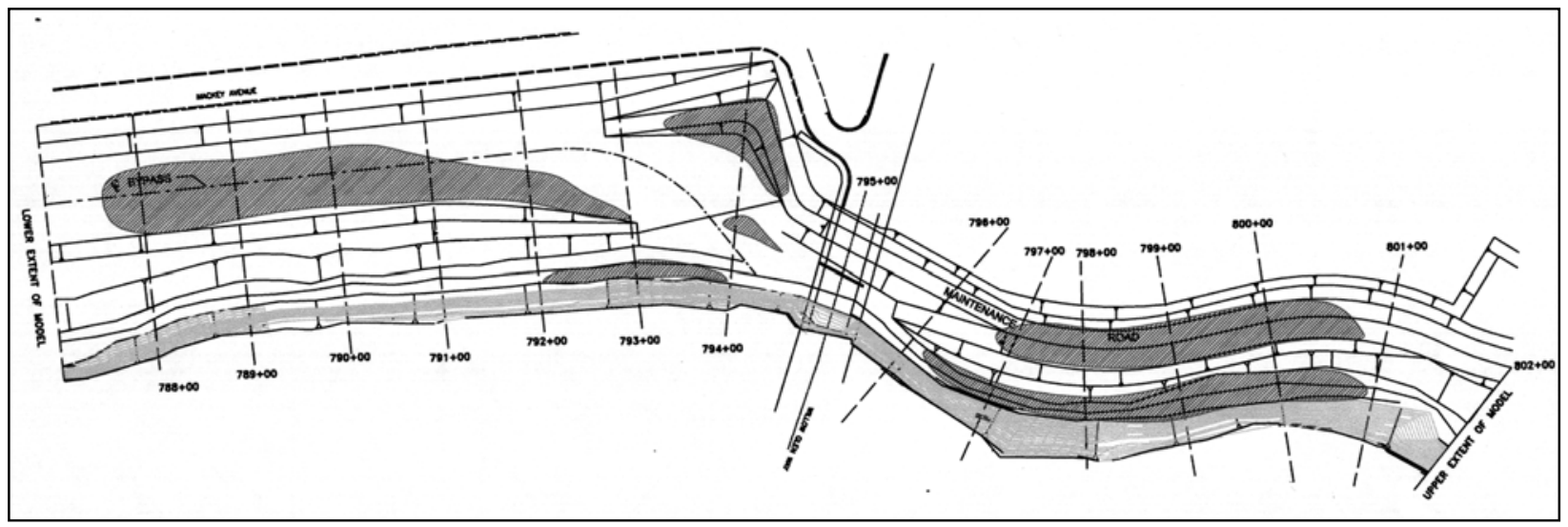

Figure 7. Sediment deposition design roughness

The flow distributions for the design roughness with and without sediment deposition are indicated in Table 6.

\begin{tabular}{|c|c|c|c|c|c|}
\hline \multicolumn{6}{|c|}{$\begin{array}{l}\text { Table } 6 \\
\text { Flow Distribution for Design Roughness with and without } \\
\text { Sediment }\end{array}$} \\
\hline \multirow[b]{2}{*}{ Event } & \multirow[b]{2}{*}{$\begin{array}{l}\text { Total } \\
\text { Discharge, cfs }\end{array}$} & \multicolumn{2}{|c|}{$\begin{array}{c}\text { Discharge Without Sediment } \\
\text { Deposits }\end{array}$} & \multicolumn{2}{|c|}{$\begin{array}{c}\text { Discharge With Sediment } \\
\text { Deposits }\end{array}$} \\
\hline & & $\begin{array}{l}\text { Natural } \\
\text { Channel }\end{array}$ & $\begin{array}{l}\text { Bypass } \\
\text { Channel } \\
\end{array}$ & $\begin{array}{l}\text { Natural } \\
\text { Channel }\end{array}$ & $\begin{array}{l}\text { Bypass } \\
\text { Channel } \\
\end{array}$ \\
\hline 1.2-year & 1,500 & 1,500 & 0 & 1,200 & 300 \\
\hline 10-year & 7,100 & 3,350 & 3,750 & 3,200 & 3,900 \\
\hline 20 -year & 9,000 & 3,800 & 5,200 & 3,750 & 5,250 \\
\hline 100-year & 14,600 & 5,000 & 9,600 & 5,800 & 8,800 \\
\hline
\end{tabular}

The water-surface elevations for the design roughness with sediment deposition are indicated in Table 7. 


\begin{tabular}{|c|c|c|c|c|c|c|c|c|}
\hline $\begin{array}{l}\text { Table } \\
\text { Water }\end{array}$ & rface & ation & Desi & oughne & vith & ient & sition & \\
\hline & Natura & annel Wa & urface El & ion, NGVD & Bypas & annel Wa & Surface E & ion, NGVD \\
\hline & & & & & & & ent & \\
\hline Station & 1.2-year & $\begin{array}{l}10 \text {-year } \\
\end{array}$ & 20-year & 100-year & 1.2-year & 10-year & 20-year & 100-year \\
\hline $801+00$ & 115.29 & 1119.25 & 120.12 & 123.09 & & & & \\
\hline $800+00$ & 115.32 & 118.74 & 119.67 & 122.07 & & & & \\
\hline $799+00$ & 115.20 & 118.35 & 119.10 & 121.26 & & & & \\
\hline $798+00$ & 113.55 & 116.64 & 118.32 & 121.05 & & & & \\
\hline $797+00$ & 111.69 & 115.47 & 117.16 & 120.63 & & & & \\
\hline $796+00$ & 111.45 & 113.07 & 113.58 & 115.44 & & & & \\
\hline $795+00$ & 111.06 & 112.92 & 113.28 & 114.87 & $\frac{3}{11}$ & & & \\
\hline $794+00$ & 110.94 & 113.37 & 113.97 & 115.65 & 운 & & & \\
\hline $793+00$ & 110.91 & 113.94 & 114.66 & 116.13 & & 111.60 & 112.68 & 114.45 \\
\hline $792+00$ & 109.77 & 112.41 & 113.94 & 116.22 & & 110.04 & 110.91 & 114.51 \\
\hline $791+00$ & 109.56 & 112.74 & 113.79 & 115.85 & & 108.48 & 110.55 & 113.94 \\
\hline $790+00$ & 108.48 & 111.09 & 113.13 & 115.77 & & 108.57 & 110.46 & 113.88 \\
\hline $789+00$ & 108.72 & 111.72 & 112.89 & 115.05 & & 109.02 & 110.43 & 114.30 \\
\hline $788+00$ & 108.57 & 111.24 & 112.50 & 115.17 & & 109.02 & 110.58 & 114.45 \\
\hline
\end{tabular}

The differences in water-surface elevation for the design roughness with and without sediment deposition are indicated in Table 8.

\begin{tabular}{|c|c|c|c|c|c|c|c|c|}
\hline \multicolumn{2}{|c|}{ Table 8} & ion & eren & or De & ous & wi & m & ded \\
\hline \multirow[b]{3}{*}{ Station } & \multicolumn{4}{|c|}{ "Natural Channel, ft } & \multicolumn{4}{|c|}{ Bypass Channel, ft } \\
\hline & \multicolumn{4}{|c|}{ Event } & \multicolumn{4}{|c|}{ Event } \\
\hline & 1.2-year & 10-year & 20-year & 100-year & 1.2-year & 10-year & 20-year & 100-year \\
\hline $801+00$ & 2.13 & 1.35 & 0.84 & 0.99 & \multirow{14}{*}{$\begin{array}{l}\frac{3}{0} \\
\frac{0}{4} \\
\frac{0}{z}\end{array}$} & & & \\
\hline $800+00$ & 2.13 & 0.60 & 0.24 & 0.00 & & & & \\
\hline $799+00$ & 2.16 & 0.39 & -0.06 & -0.39 & & & & \\
\hline $798+00$ & 0.87 & -0.93 & -0.57 & -0.51 & & & & \\
\hline $797+00$ & -0.21 & -1.02 & -0.62 & 0.27 & & & & \\
\hline $796+00$ & 0.94 & 0.60 & 0.51 & 0.27 & & & & \\
\hline \begin{tabular}{|l|}
$795+00$ \\
\end{tabular} & 0.63 & 0.45 & 0.42 & -0.03 & & & & \\
\hline $794+00$ & 0.60 & 0.09 & 0.39 & 0.21 & & & & \\
\hline $793+00$ & 0.75 & 0.75 & 0.72 & 0.33 & & 2.10 & 1.56 & -0.54 \\
\hline $\begin{array}{l}792+00 \\
\end{array}$ & 0.18 & -0.45 & 0.06 & -0.06 & & 0.51 & -0.27 & -0.54 \\
\hline $791+00$ & 0.48 & 0.69 & 0.57 & 0.23 & & -0.78 & -2.1 & -0.69 \\
\hline $790+00$ & -0.66 & -0.90 & 0.03 & 0.18 & & -0.45 & -0.06 & -0.48 \\
\hline $789+00$ & -0.12 & 0.21 & 0.21 & $\begin{array}{l}-0.15 \\
\end{array}$ & & 0.06 & -0.06 & 0.12 \\
\hline \begin{tabular}{|l|}
$788+00$ \\
\end{tabular} & 0.02 & 0.00 & 0.00 & 0.00 & & -0.03 & 0.00 & 0.06 \\
\hline
\end{tabular}




\section{New Channel Roughness}

\section{Flow distribution}

The flow distributions for the new channel roughness were recorded to document the distributions associated with a lower water surface produced by the new channel Manning coefficient (Table 1). The resulting distributions are shown in Table 9. Less flow was passed to the bypass channel for the new channel roughness condition.

\begin{tabular}{|c|c|c|c|}
\hline \multicolumn{4}{|c|}{$\begin{array}{l}\text { Table } 9 \\
\text { Flow Distributions for New Channel Roughness }\end{array}$} \\
\hline Event & $\begin{array}{l}\text { Discharge, } \\
\text { cfs }\end{array}$ & $\begin{array}{l}\text { Natural Channel Discharge, } \\
\text { cfs }\end{array}$ & $\begin{array}{l}\text { Bypass Channel Discharge, } \\
\text { cfs }\end{array}$ \\
\hline 1.2-year & 1,500 & 1,500 & 0 \\
\hline 10-year & 7,100 & 3,600 & 3,500 \\
\hline 20 -year & 9,000 & 4,100 & 4,900 \\
\hline 100-year & 14,600 & 5,700 & 8,900 \\
\hline
\end{tabular}

\section{Tailwater sensitivity}

Flow distributions were documented for several tailwater elevations to determine the weir efficiency with respect to changes in tailwater elevation. The tailwater elevation in each channel (natural and bypass) was increased or decreased simultaneously by the amount indicated in the table. The resulting distributions are shown in Table 10.

\begin{tabular}{|c|c|c|c|c|}
\hline \multicolumn{5}{|c|}{$\begin{array}{l}\text { Table } 10 \\
\text { Flow Distribution for New Channel Roughness }\end{array}$} \\
\hline Event & $\begin{array}{l}\text { Discharge, } \\
\text { cfs }\end{array}$ & $\begin{array}{l}\text { Natural Channel } \\
\text { Discharge, cfs }\end{array}$ & $\begin{array}{l}\text { Bypass Channel } \\
\text { Discharge, cfs }\end{array}$ & Tailwater \\
\hline \multirow[t]{4}{*}{1.2 -year } & \multirow[t]{4}{*}{1,500} & 1,500 & 0 & $-1.0-\mathrm{ft}$ \\
\hline & & 1,500 & 0 & Design \\
\hline & & 1,500 & 0 & $+1.0-\mathrm{ft}$ \\
\hline & & 1,400 & 100 & $+2.0-\mathrm{ft}$ \\
\hline \multirow[t]{4}{*}{ 10-year } & \multirow[t]{4}{*}{7,100} & 3,600 & 3,500 & $-1.0-\mathrm{ft}$ \\
\hline & & 3,600 & 3,500 & Design \\
\hline & & 3,450 & 3,650 & $+1.0-\mathrm{ft}$ \\
\hline & & 3,300 & 3,800 & $+2.0-\mathrm{ft}$ \\
\hline \multirow[t]{4}{*}{ 20-year } & \multirow[t]{4}{*}{9,000} & 4,150 & 4,850 & $-1.0-\mathrm{ft}$ \\
\hline & & 4,100 & 4,900 & Design \\
\hline & & 4,000 & 5,000 & $+1.0-\mathrm{ft}$ \\
\hline & & 3,650 & 5,350 & $+2.0-\mathrm{ft}$ \\
\hline \multirow[t]{4}{*}{ 100-year } & \multirow[t]{4}{*}{14,600} & 5,700 & 8,900 & $-1.0-\mathrm{ft}$ \\
\hline & & 5,700 & 8,900 & Design \\
\hline & & 5,800 & 8,800 & $+1.0-\mathrm{ft}$ \\
\hline & & 6,000 & 8,600 & $+2.0-\mathrm{ft}$ \\
\hline
\end{tabular}




\section{Water-surface profiles}

Water-surface profiles were documented for the four flow events with four tailwater elevations. These data are presented in Table 11 and drawings in Appendix C.

\begin{tabular}{|c|c|c|c|c|c|c|c|c|}
\hline \multicolumn{9}{|c|}{$\begin{array}{l}\text { Table } 11 \\
\text { Water-Surface Elevations for New Channel Roughness }\end{array}$} \\
\hline \multirow[b]{3}{*}{ Station } & \multicolumn{4}{|c|}{ Natural Channel Water-Surface Elevation, NGVD } & \multicolumn{4}{|c|}{ Bypass Channel Water-Surface Elevation, NGVD } \\
\hline & \multicolumn{4}{|c|}{ Event } & \multicolumn{4}{|c|}{ Event } \\
\hline & 1.2-year & 10-year & 20-year & 100-year & 1.2-year & 10-year & 20-year & 100-year \\
\hline $801+00$ & 112.92 & 117.90 & 119.22 & 122.34 & \multirow{14}{*}{$\begin{array}{l}\frac{3}{0} \\
\frac{0}{1} \\
\text { 은 }\end{array}$} & & & \\
\hline $800+00$ & 113.04 & 118.23 & 119.49 & 122.40 & & & & \\
\hline $799+00$ & 112.86 & 117.90 & 119.23 & 121.98 & & & & \\
\hline $798+00$ & 112.50 & 117.60 & 119.01 & 121.74 & & & & \\
\hline $797+00$ & 111.66 & 116.49 & 117.78 & 120.66 & & & & \\
\hline $796+00$ & 110.22 & 112.47 & 112.92 & 115.11 & & & & \\
\hline $795+00$ & 110.01 & 112.53 & 112.74 & 114.48 & & & & \\
\hline $794+00$ & 109.98 & 112.98 & 113.52 & 115.02 & & & & \\
\hline $793+00$ & 109.89 & 113.28 & 113.85 & 115.38 & & 109.11 & 110.64 & 114.42 \\
\hline $792+00$ & 109.14 & 112.56 & 113.85 & 115.95 & & 109.08 & 110.73 & 114.75 \\
\hline $791+00$ & 108.84 & 111.78 & 112.71 & 114.90 & & 108.93 & 110.46 & 114.21 \\
\hline $790+00$ & 108.69 & 111.66 & 112.74 & 114.93 & & 108.57 & 110.07 & 113.79 \\
\hline $789+00$ & 108.42 & 111.18 & 112.02 & 114.21 & & 108.60 & 109.98 & 113.76 \\
\hline $788+00$ & 108.12 & 110.61 & 111.69 & 114.06 & & 108.60 & 110.16 & 113.94 \\
\hline
\end{tabular}

\section{Flow velocities}

Velocities were higher for the new channel roughness condition. Since scour potential is based on velocity, this condition was documented. Flow velocities were measured in the vicinity of the weir and bridge pier to indicate the erosion potential of the channel. Velocities were also measured at the upstream and downstream extent of the model. Velocity measurement locations are shown in Figure 8.

Velocity data are shown in Plates 1 through 16. 


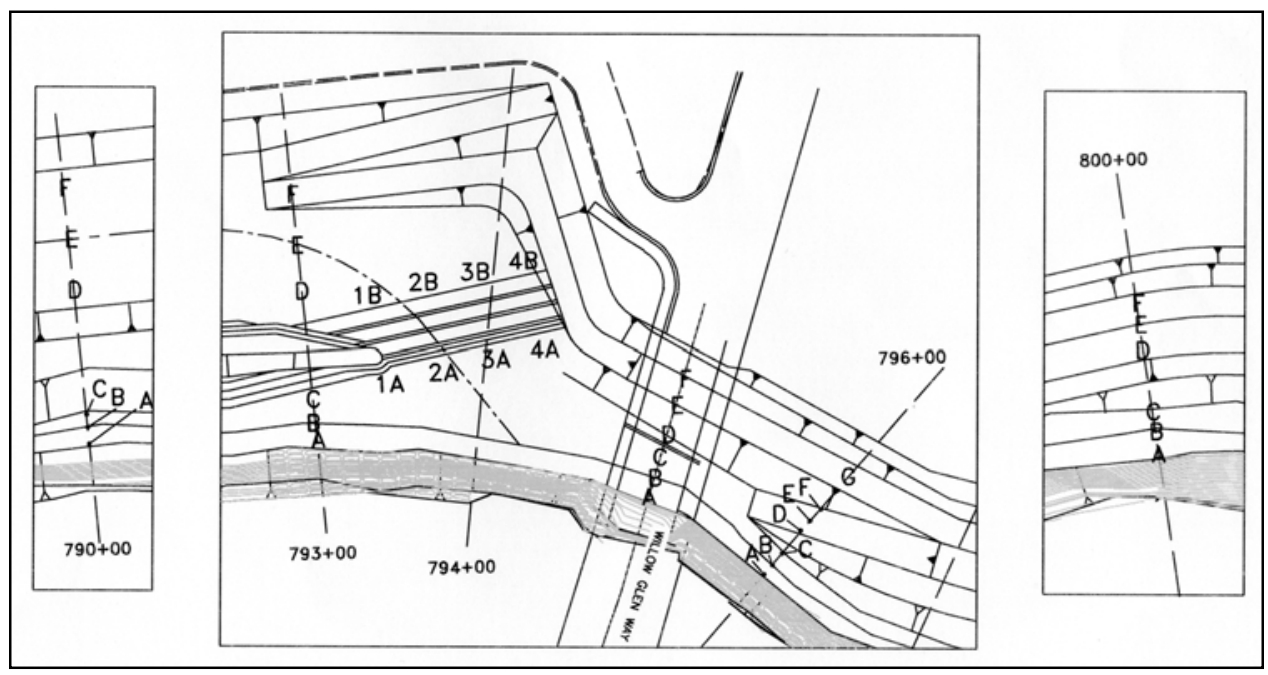

Figure 8. Velocity measurement locations

\section{Sediment impact}

Sediment was again introduced in the model to illustrate areas of likely deposition for the new channel roughness. The magnitude (quantity) of this deposition is not relative to prototype expectations. The procedure and material were the same as that used for the design roughness configuration. Figure 9 is a plan view of the model showing areas of sediment deposition.

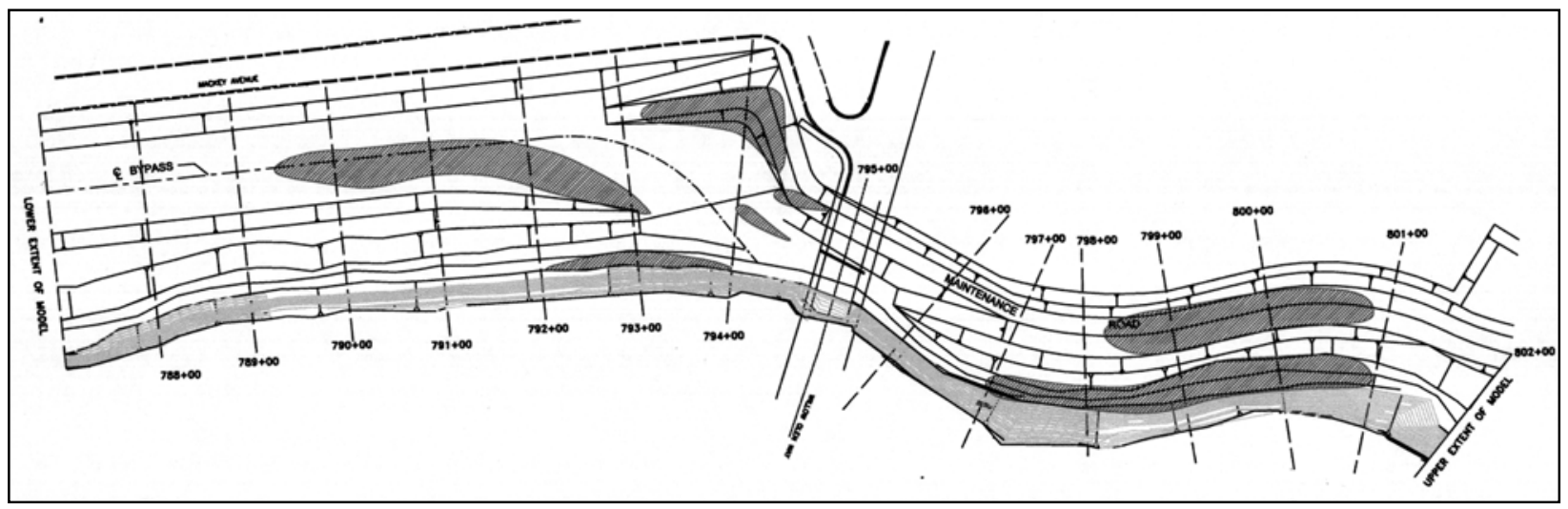

Figure 9. Sediment deposition new channel roughness

The flow distributions for the new channel roughness with and without sediment deposition are indicated in Table 12.

\begin{tabular}{|c|c|c|c|c|c|}
\hline \multicolumn{6}{|c|}{$\begin{array}{l}\text { Table } 12 \\
\text { Flow Distribution for New Channel Roughness with and without } \\
\text { Sediment }\end{array}$} \\
\hline \multirow[b]{2}{*}{ Event } & \multirow[b]{2}{*}{$\begin{array}{l}\text { Total } \\
\text { Discharge, cfs }\end{array}$} & \multicolumn{2}{|c|}{$\begin{array}{c}\text { Discharge Without Sediment } \\
\text { Deposits }\end{array}$} & \multicolumn{2}{|c|}{$\begin{array}{c}\text { Discharge With Sediment } \\
\text { Deposits }\end{array}$} \\
\hline & & $\begin{array}{l}\text { Natural } \\
\text { Channel }\end{array}$ & $\begin{array}{l}\text { Bypass } \\
\text { Channel }\end{array}$ & $\begin{array}{l}\text { Natural } \\
\text { Channel }\end{array}$ & $\begin{array}{l}\text { Bypass } \\
\text { Channel }\end{array}$ \\
\hline$\overline{c 1.2 \text { year }}$ & $\begin{array}{l}1,500 \\
\end{array}$ & $\overline{c 1,500}$ & $\overline{0}$ & $\begin{array}{l}1,400 \\
\end{array}$ & $\begin{array}{ll}100 \\
\end{array}$ \\
\hline 10 year & 7,100 & 3,600 & 3,500 & 3,450 & 3,650 \\
\hline 20 year & 9,000 & 4,100 & 4,900 & 4,050 & 4,950 \\
\hline 100 year & 14,600 & 5,700 & 8,900 & 5,900 & 8,700 \\
\hline
\end{tabular}




\section{Discussion and Summary of Results}

\section{Flow Distribution}

The flow distributions associated with the final weir design (Figure 6) met the initial requirements set by the San Francisco District. This is based on results for the channel representing the design roughness. The model results indicate a maximum of 1,500-cfs natural channel flow before the bypass channel is utilized. The flow distribution for the 100 -year event is $5,000 \mathrm{cfs}$ in the natural channel and 9,600 cfs in the bypass channel. These two distributions are indicative of a weir design that satisfies the original design requirements.

\section{Tailwater Sensitivity}

Flow distributions were recorded for each event with changes in tailwater elevation. These elevations were: the design; design $-1.0 \mathrm{ft}$; design $+1.0 \mathrm{ft}$; and design $+2.0 \mathrm{ft}$. While there were some changes in distribution resulting from changes in tailwater elevation, they are considered to be small variations. The maximum distribution variation was $600 \mathrm{cfs}$ for the 10 -year event with the design roughness and $450 \mathrm{cfs}$ for the 20 -year event with the new channel roughness. This small change in distribution with respect to tailwater change was attributed to the weir's location. It is located at the downstream extent of a supercritical zone near the Willow Glenn Way bridge. The water-surface elevation in a region of supercritical flow is not controlled by tailwater, and therefore is not responsive to these tailwater elevation changes.

The left end of the weir (end closest to the natural channel) is near a jump area (transitioning from supercritical to subcritical flow) in the natural channel. This affected area of the weir is responsible for the small changes in distribution. If the weir were located entirely in the supercritical flow, no changes in distribution would be expected due to tailwater changes unless the tailwater changes were large enough to change the flow regime at the weir. 


\section{Water-Surface Profiles}

The water-surface elevation was measured for each event with the fourtailwater elevation previously described and with the two different channel roughnesses. The changes were significant, but the river discharge was contained within the channels. The only exception was for the 100-year event with the design $+2.0-\mathrm{ft}$ tailwater elevation. During this event the natural channel overtopped on the right bank and spilled into the bypass channel. No overtopping occurred on the landside of either channel, thus indicating proper design of channel dimensions to prevent overtopping.

\section{Flow Velocities}

Flow velocities were considered to be most critical or at their highest with the new channel (smoothest) roughness (Table 1). Therefore, channel velocities were measured in the supercritical zone near the bridge pier and the weir for the new channel roughness configuration. The highest observed velocities were for the 100 -year event. These velocities reached as high as 20 -fps near the weir and 26.5-fps under the bridge. At these velocities, channel protection would be required to prevent channel erosion.

\section{Sediment Impact}

The sediment used in the model study was not a representation of the prototype sediment material. The model material was much larger and therefore could not be used to indicate quantities of deposition. This portion of the study is primarily for the demonstration of areas in the channels where sediment will likely deposit. The areas of deposition are shown in Figures 7 and 9.

The flow distributions with and without sediment tabulated in Table 6 show that the changes in flow distribution for the 100 -year event is insignificant (approximately 0.5 percent of the total flow).

\section{Willow Glenn Way Bridge}

The Willow Glenn Way bridge pier (single pier) alignment had a significant impact on the distribution of flow between the two channels. The pier design and location was provided by the San Francisco District. The pier orientation was determined in the model. It was oriented to be streamlined in the flow, thus reducing its influence in the flow field. This orientation provided the least impact on flow distributions.

The pier was moved across the channel up to $10 \mathrm{ft}$ toward the right bank and up to $10 \mathrm{ft}$ toward the left bank. These location adjustments did not impact the flow distributions as long as the pier orientation (intersect angle with the weir) was not changed. Changes in the pier orientation will direct flow either into or 
away from the weir thus changing its performance. Figure 10 shows the bridge pier as located in the model.

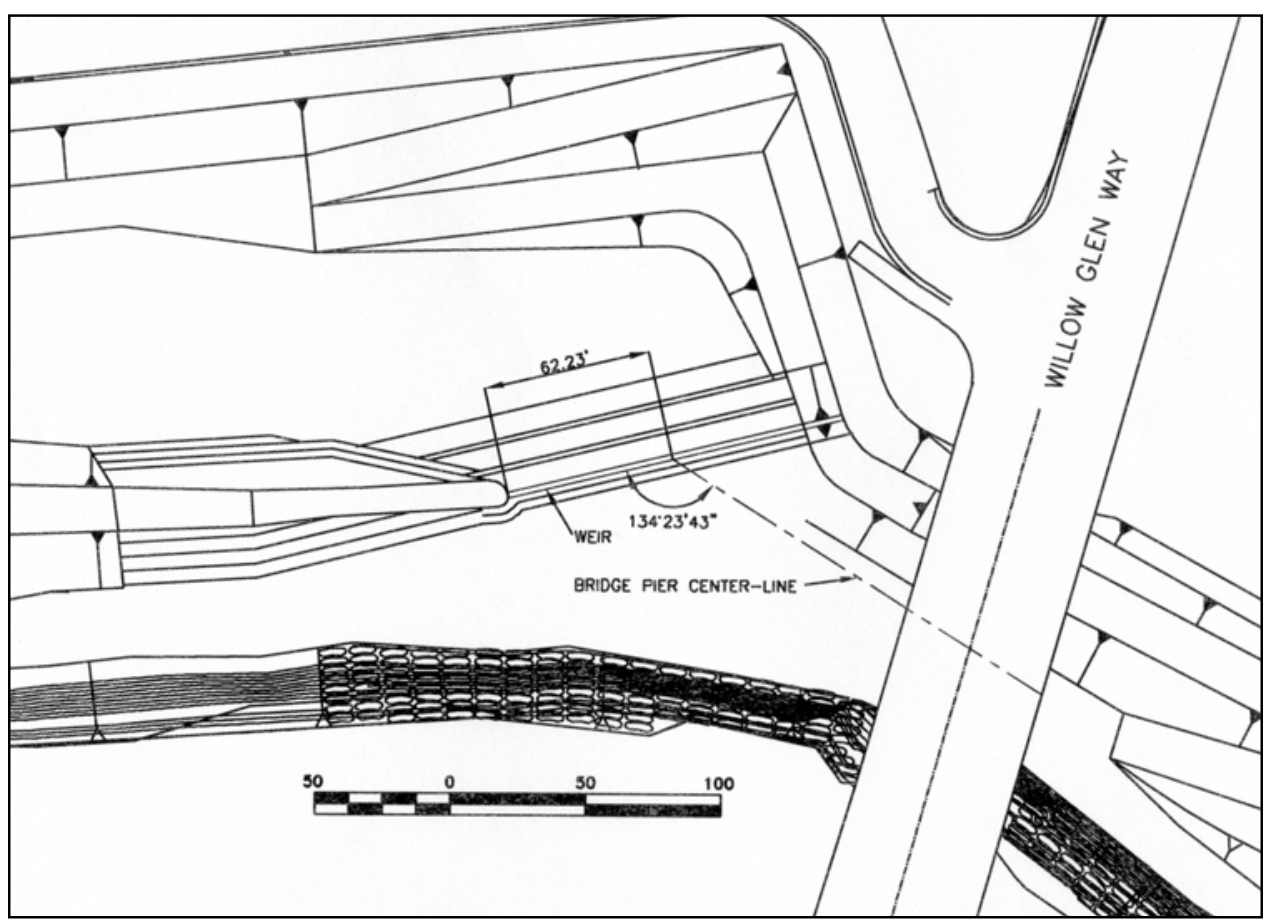

Figure 10. Upper Guadalupe bridge pier center-line location Willow Glen Way

To determine the bridge freeboard, the model bridge pier was marked to show the lowest soffit elevation of 123.27. ${ }^{1}$ Freeboard measurements were measured with and without debris buildup on the pier. Model debris consisted of a packing material commonly known as rubberized hair. The rubberized hair was sized to simulate approximately 8 -ft wide debris buildup. The freeboard was measured from the mark at el 123.27 to the water surface. The data are shown in Table 13. As mentioned in the report, the bridge pier is located in a supercritical flow regime. The debris buildup prevented "ride-up" of flow on the pier and increased the freeboard.

\section{Table 13}

Willow Glen Way Bridge Freeboard, 100-Year Event, with and without Debris on Pier

\begin{tabular}{||l|l|l||}
\hline \hline Tailwater & Freeboard without Debris, ft & Freeboard with Debris, ft \\
\hline \hline$-1.0^{\prime}$ & 2.1 & 7.5 \\
\hline Design & 2.1 & 6.9 \\
\hline$+1.0^{\prime}$ & 2.1 & 6.9 \\
\hline$+2.0^{\prime}$ & 2.1 & 6.9 \\
\hline
\end{tabular}

\footnotetext{
${ }^{1}$ All elevations (el) cited herein are in feet as referred to in the National Geodetic Vertical Datum (NGVD) of 1929. To convert feet to meters, multiply by 0.3048 .
} 


\section{Conclusions and Recommendations}

\section{Weir Design}

The final weir design (Figure 6) will provide flow distributions that meet the original design requirements. The design requirements, as stated by the San Francisco District, were to pass a 1.2-year event $(1,500 \mathrm{cfs})$ in the natural channel and to distribute the 100 -year event $(14,600 \mathrm{cfs})$ with 5,000 cfs in the natural channel and 4,600 cfs in the bypass channel.

This weir design and location does not appear to be sensitive to tailwater elevation changes ranging from the design tailwater elevation $-1.0 \mathrm{ft}$ to the design tailwater elevation $+2.0 \mathrm{ft}$. Nor does this weir configuration appear sensitive to channel sedimentation (as conducted in the study).

The weir performance is sensitive to the bridge pier (Willow Glen Way bridge) alignment. However, this study indicates that the pier location can be moved plus or minus $10 \mathrm{ft}$ (left or right) without affecting the weir performance.

Any deviations in weir or bridge pier design should be model studied to insure the weir performance is not changed.

\section{Flow Velocities}

The velocities in the natural channel near the bridge and in both channels near the weir are in excess of $20 \mathrm{fps}$. If the San Francisco District determines these velocities will erode the channel material, steps should be taken to stabilize the channel. At these high velocities, large diameter riprap or a concrete line channel may be necessary.

If the channel is not stabilized, grade control structures should be used to maintain the channel geometry. If the channel geometry is allowed to change, the flow regime (supercritical and subcritical flow) will change and require additional model evaluation to ensure proper weir performance. 


\section{References}

Hite, J. E., Jr., (1998). "Guadalupe River and bypass culvert, San Jose, California," TR CHL-98-5, U.S. Army Engineer Waterways Experiment Station, Vicksburg, MS.

King, H. W., and Brater, E. F. (1976). Handbook of hydraulics. McGraw-Hill, Inc.

Rouse, H. (1946). Elementary mechanics of fluids. John Wiley and Sons, New York.

U.S. Department of the Interior. (1984). Water measurement manual - A water resources technical publication. 3rd ed., Bureau of Reclamation. 


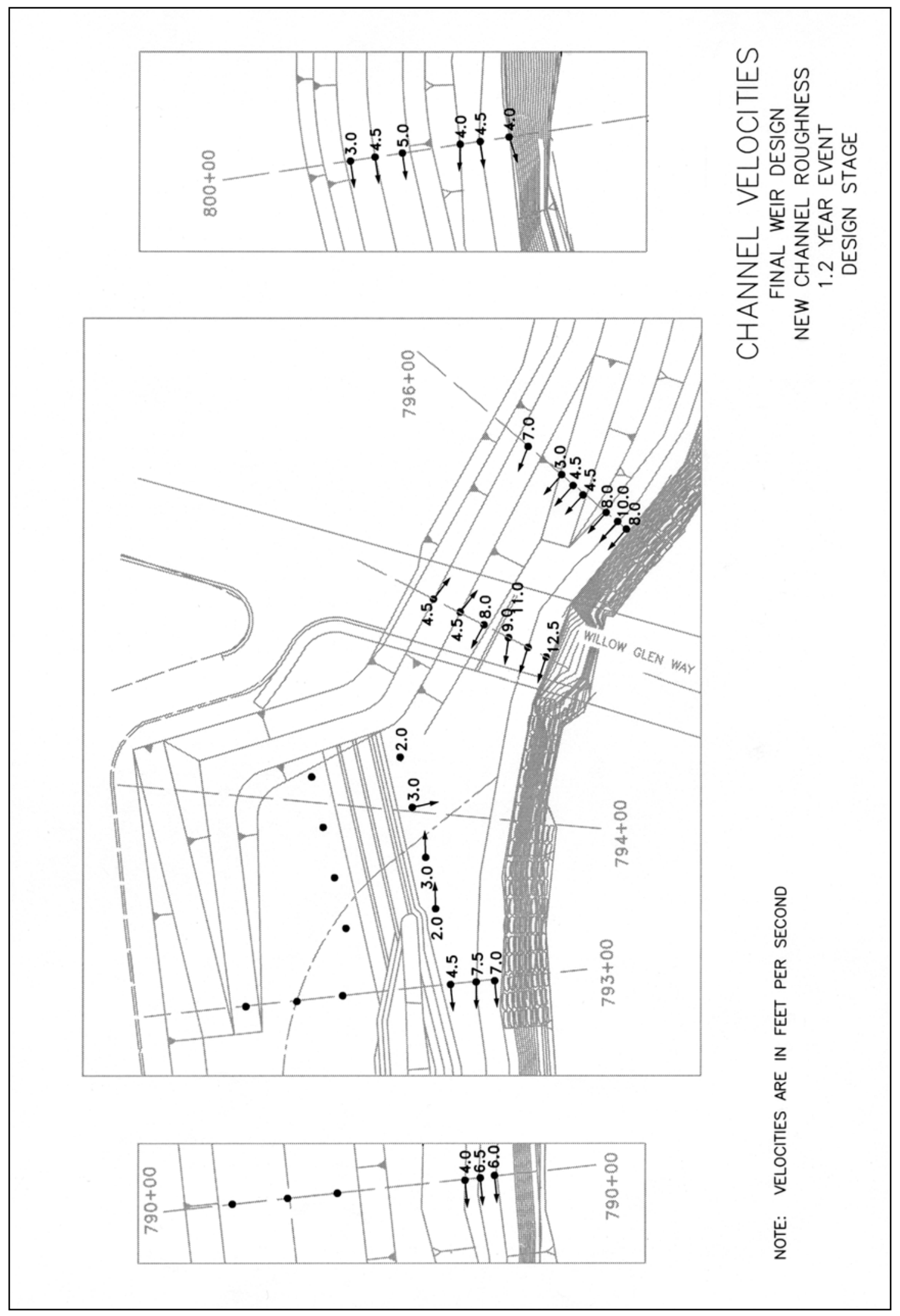

Plate 1 


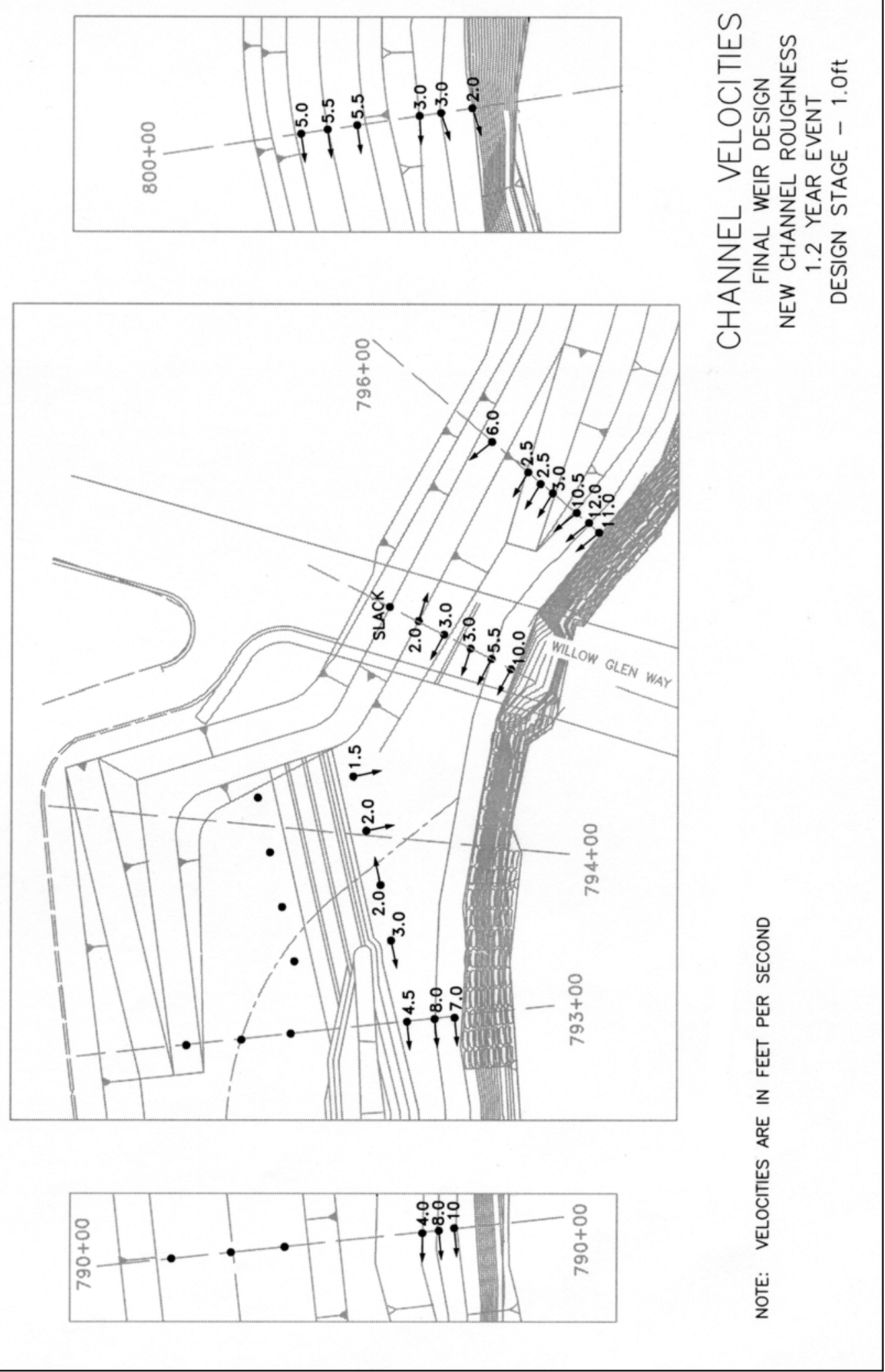

Plate 2 


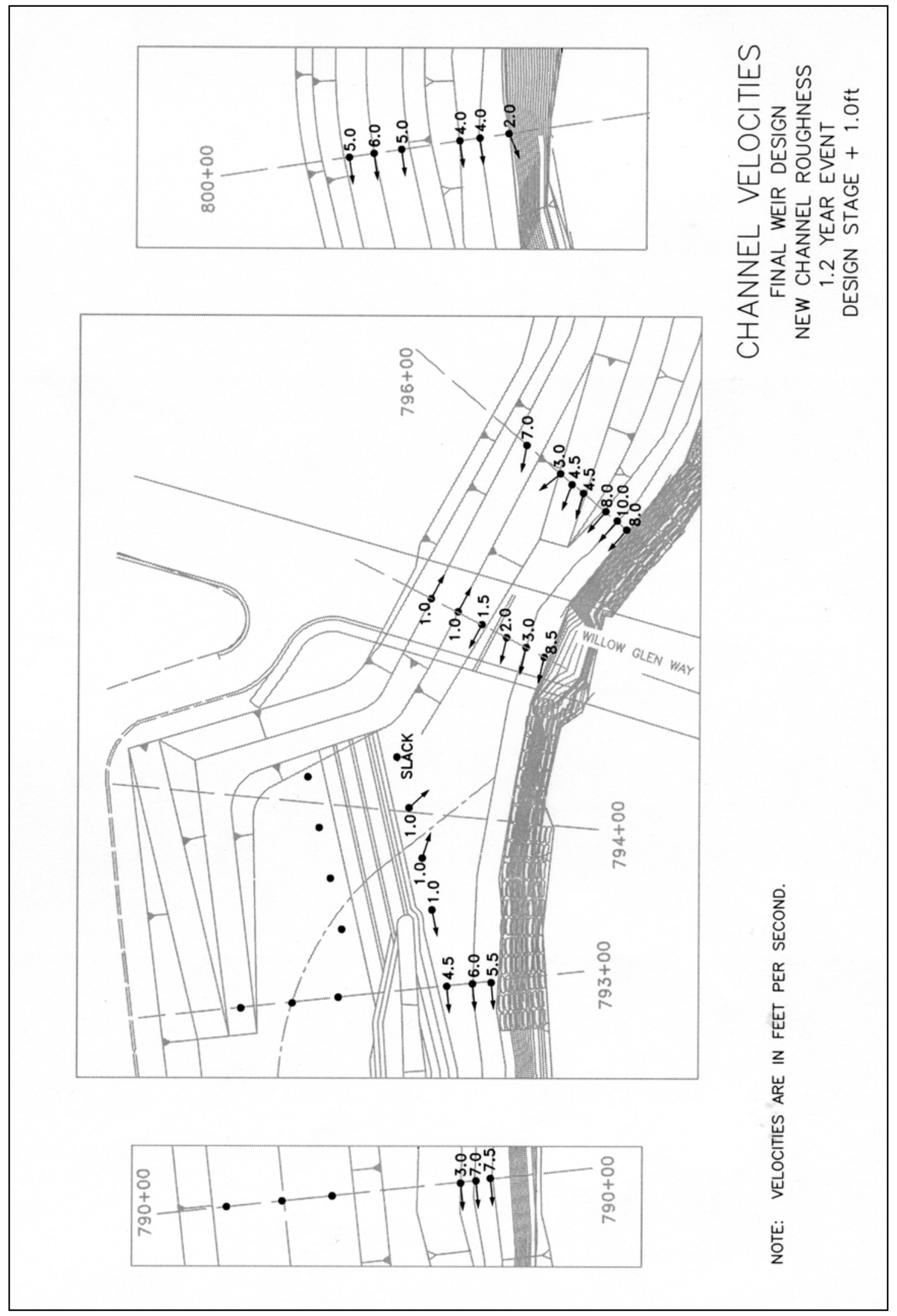

Plate 3 


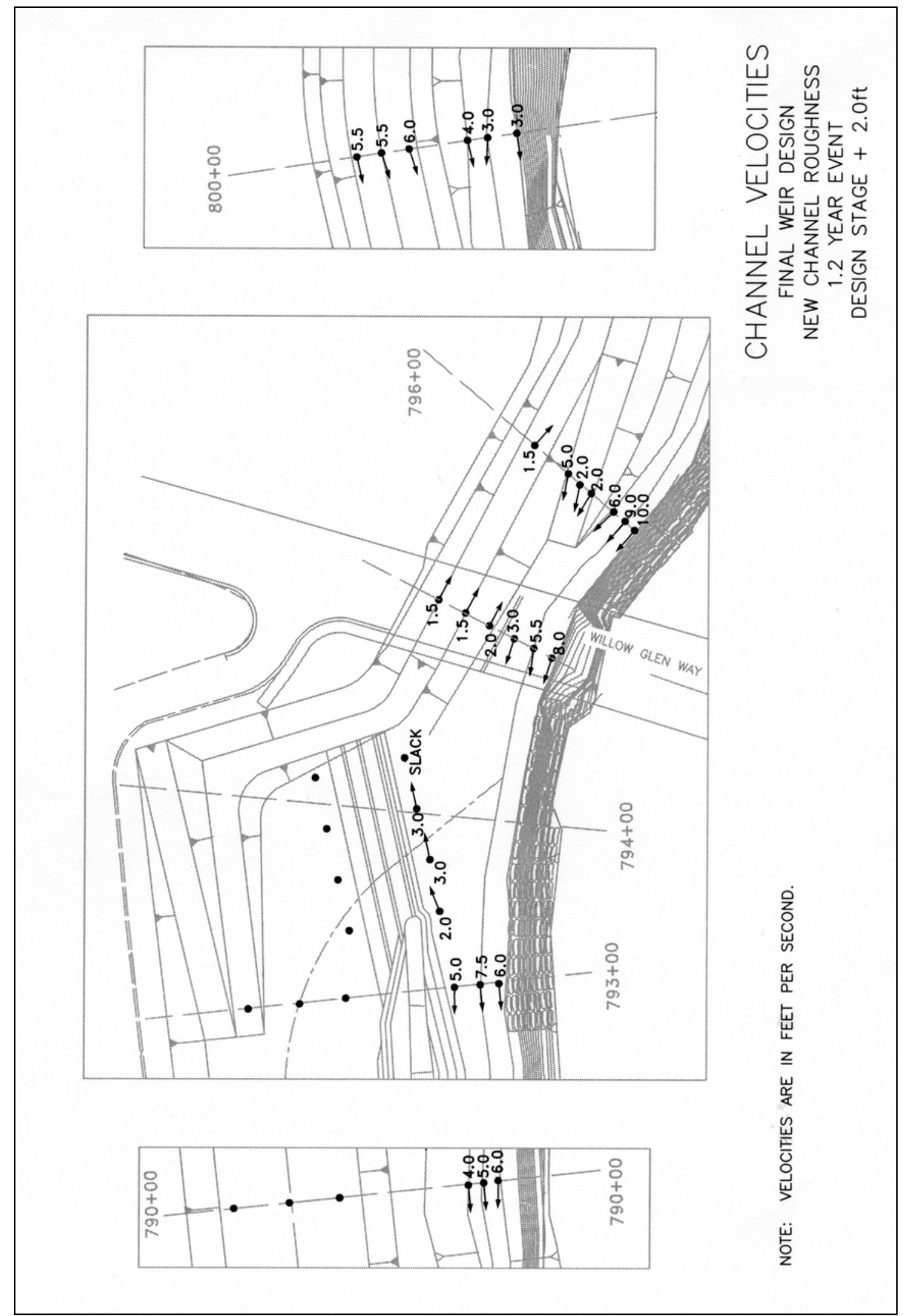

Plate 4 


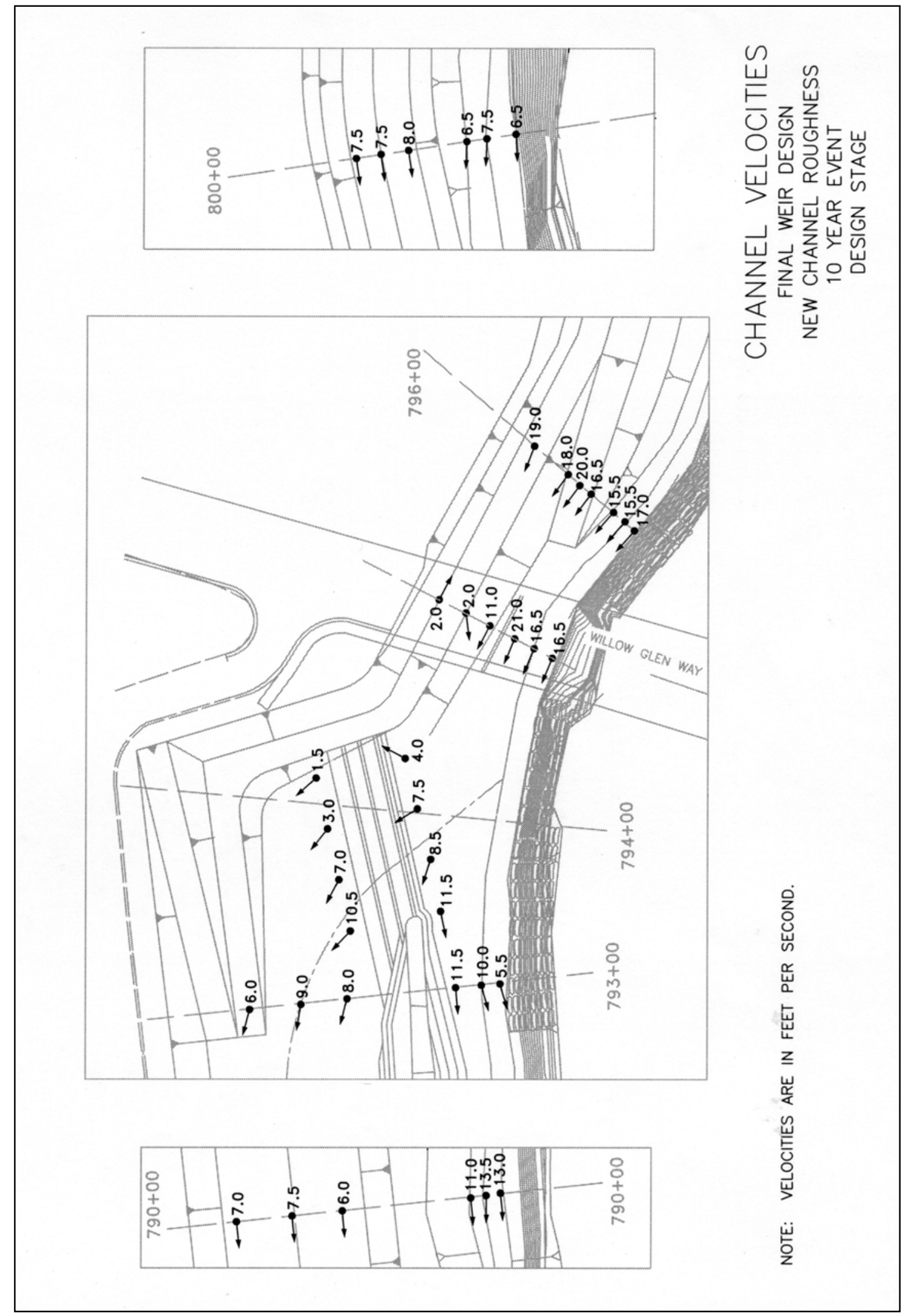

Plate 5 


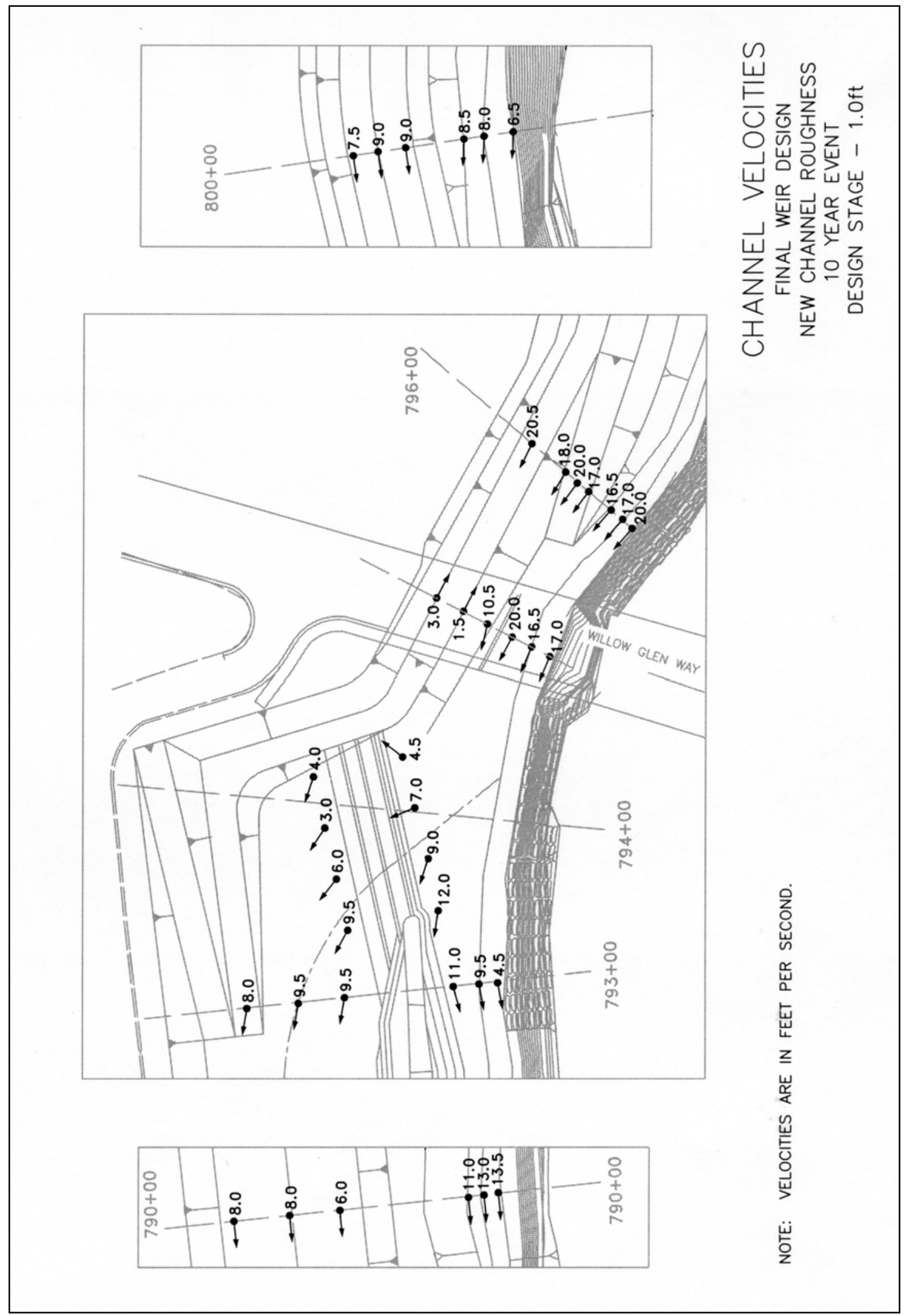

Plate 6 


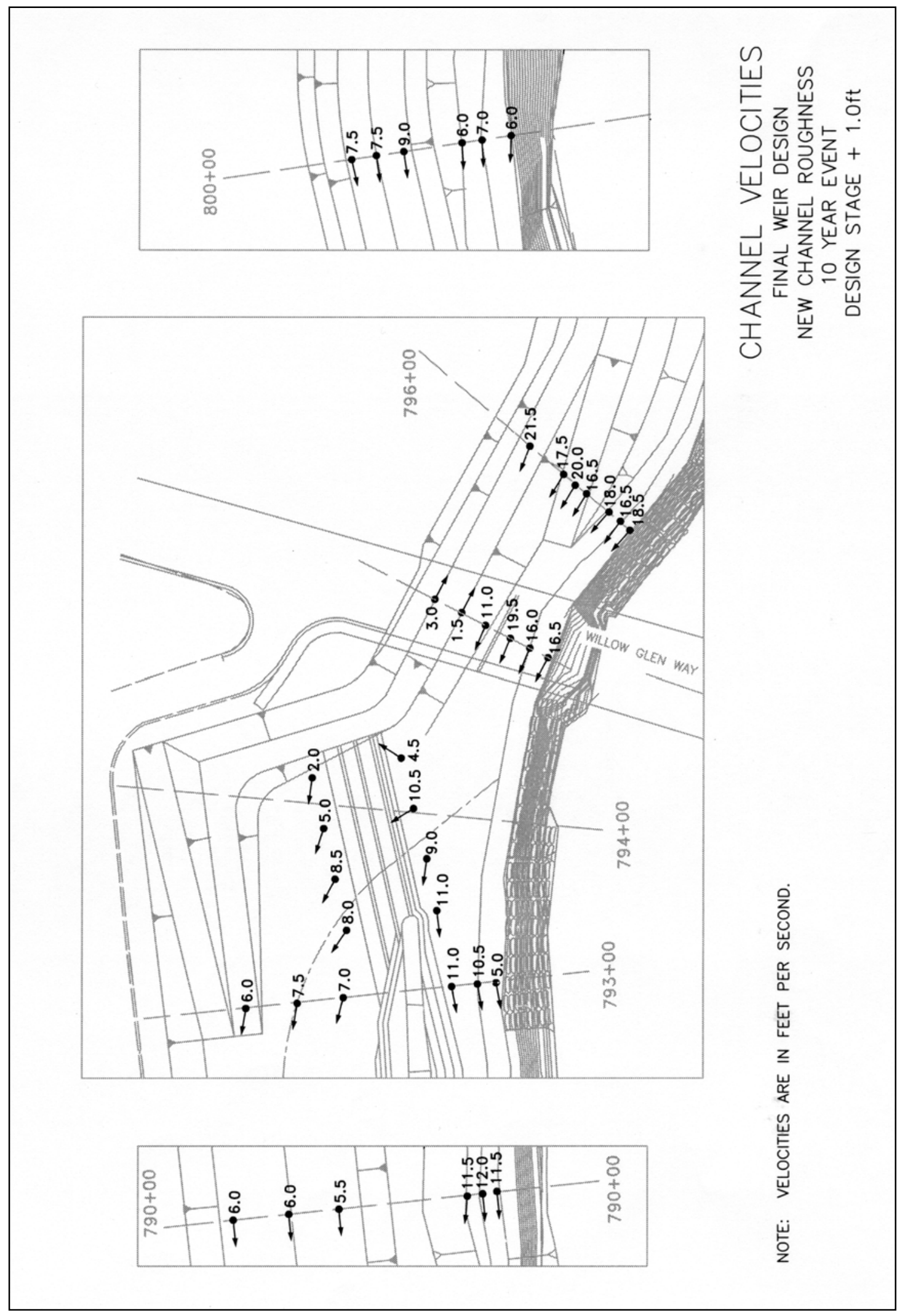

Plate 7 


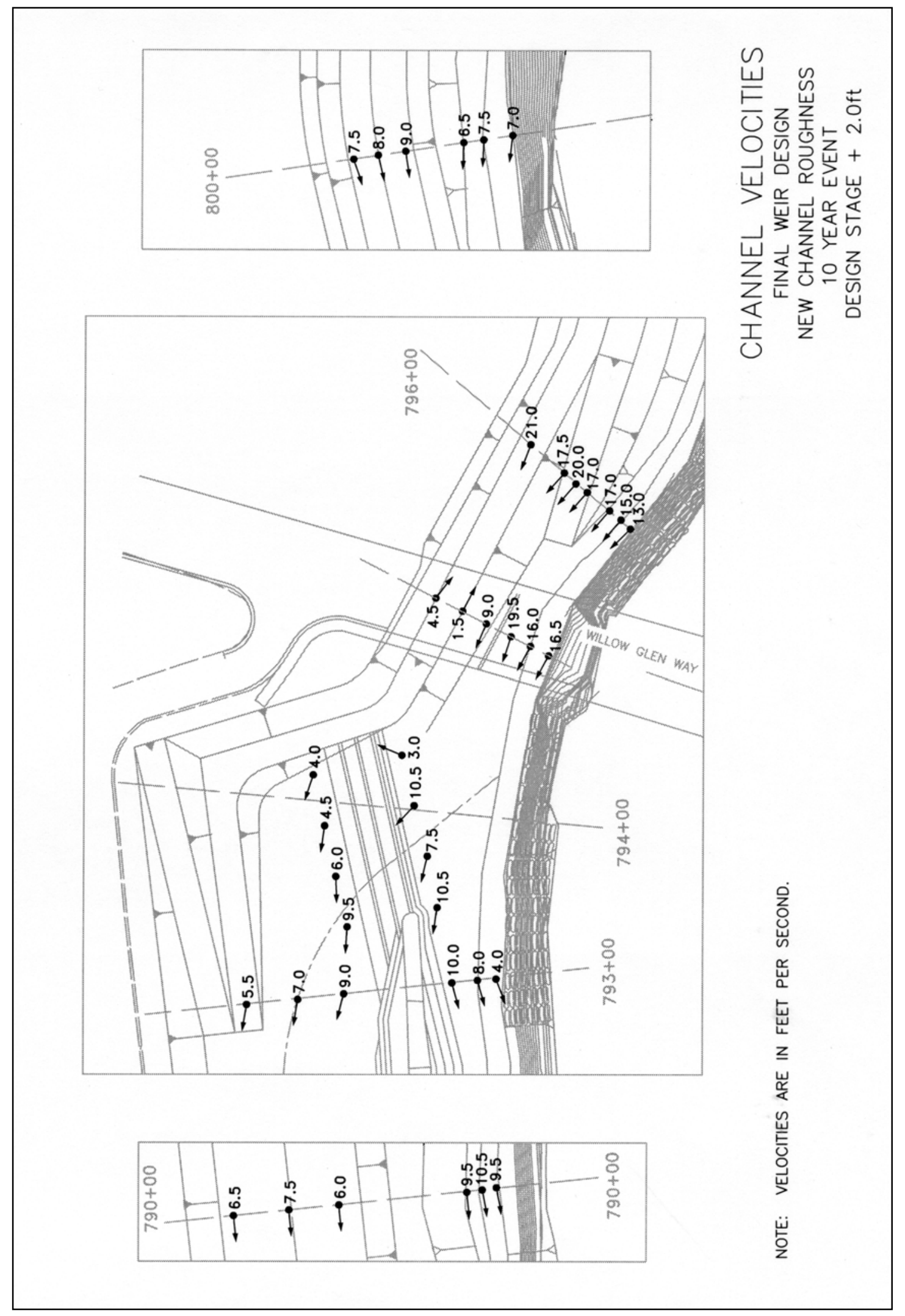

Plate 8 


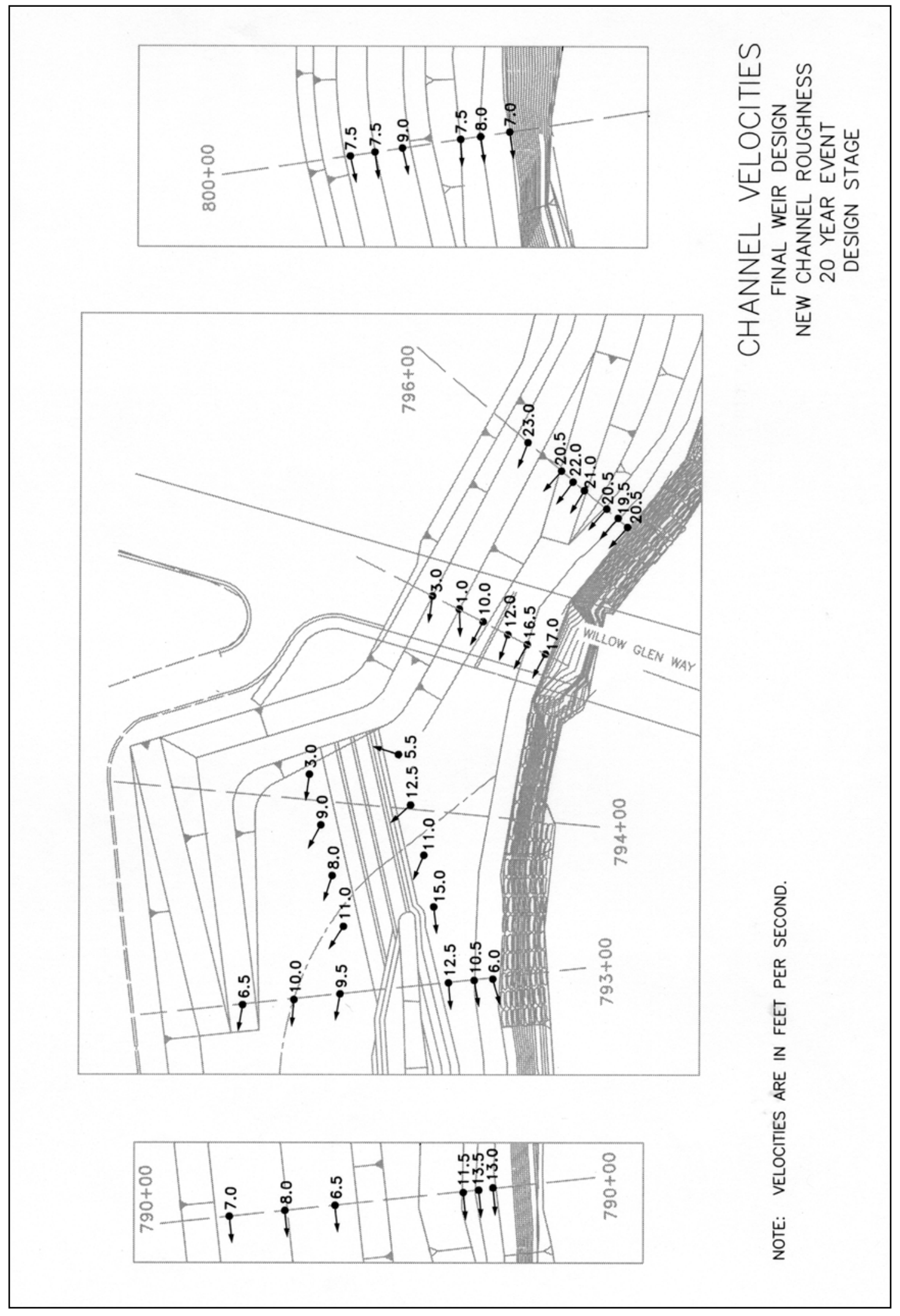

Plate 9 


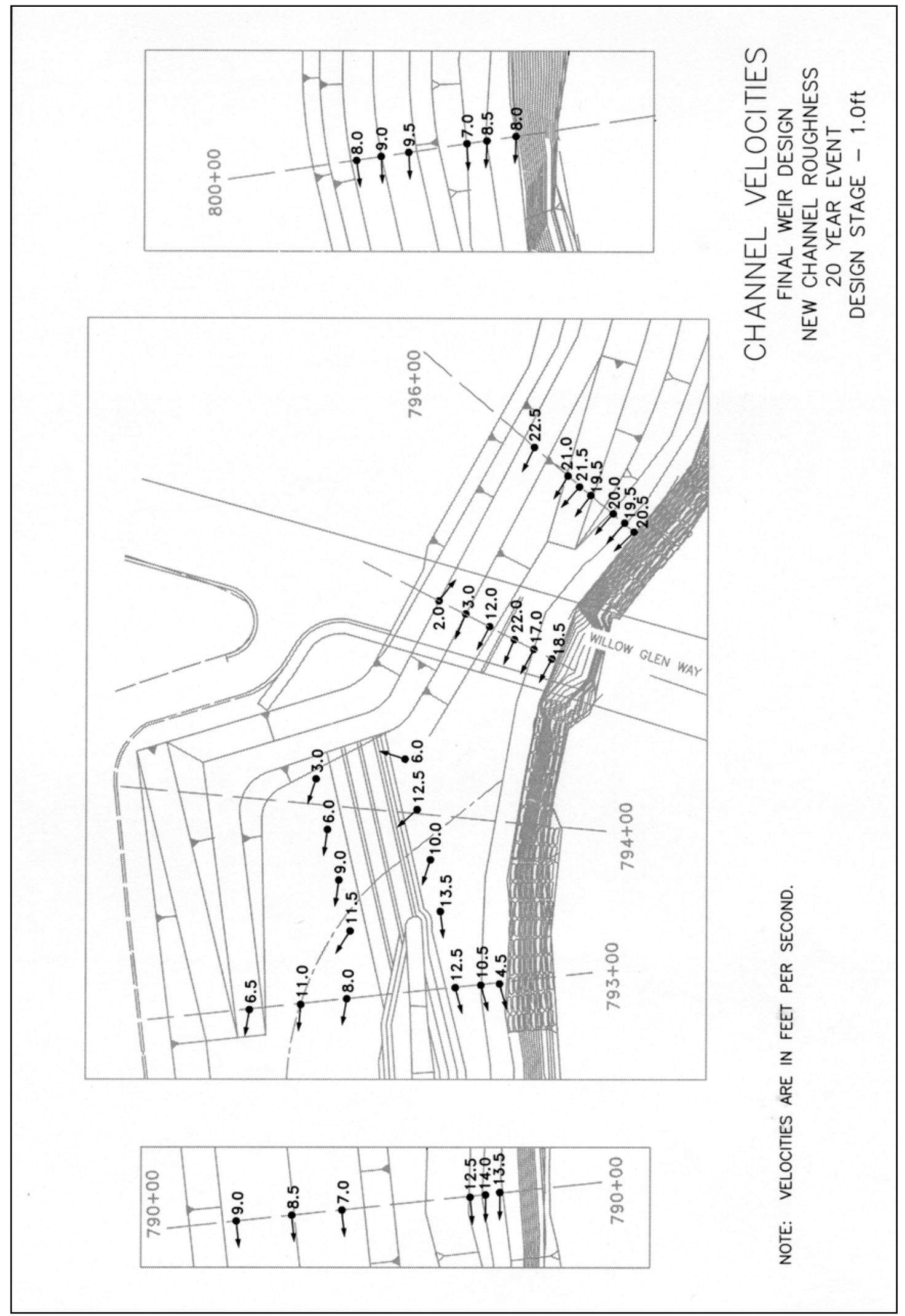

Plate 10 


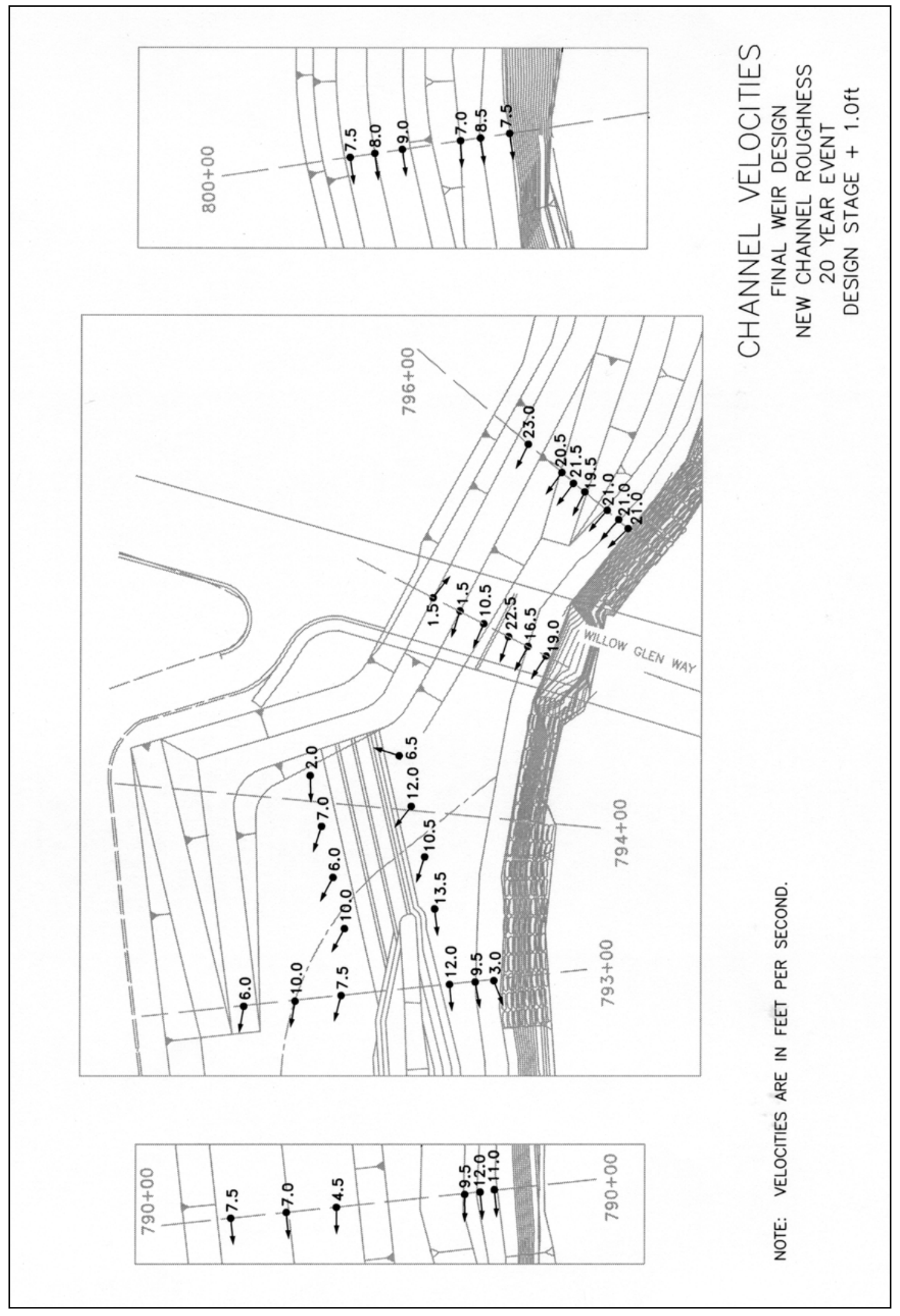

Plate 11 


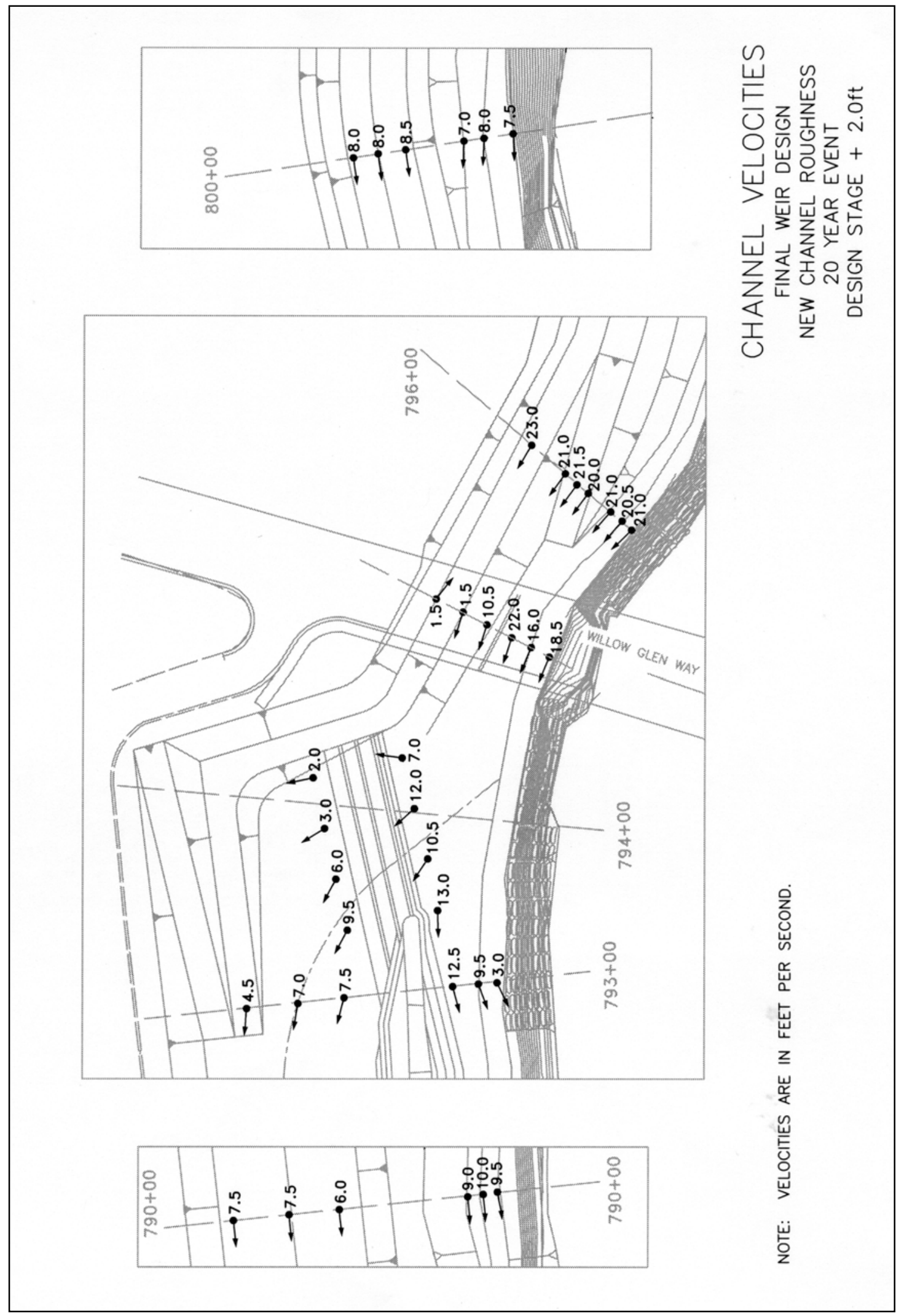

Plate 12 


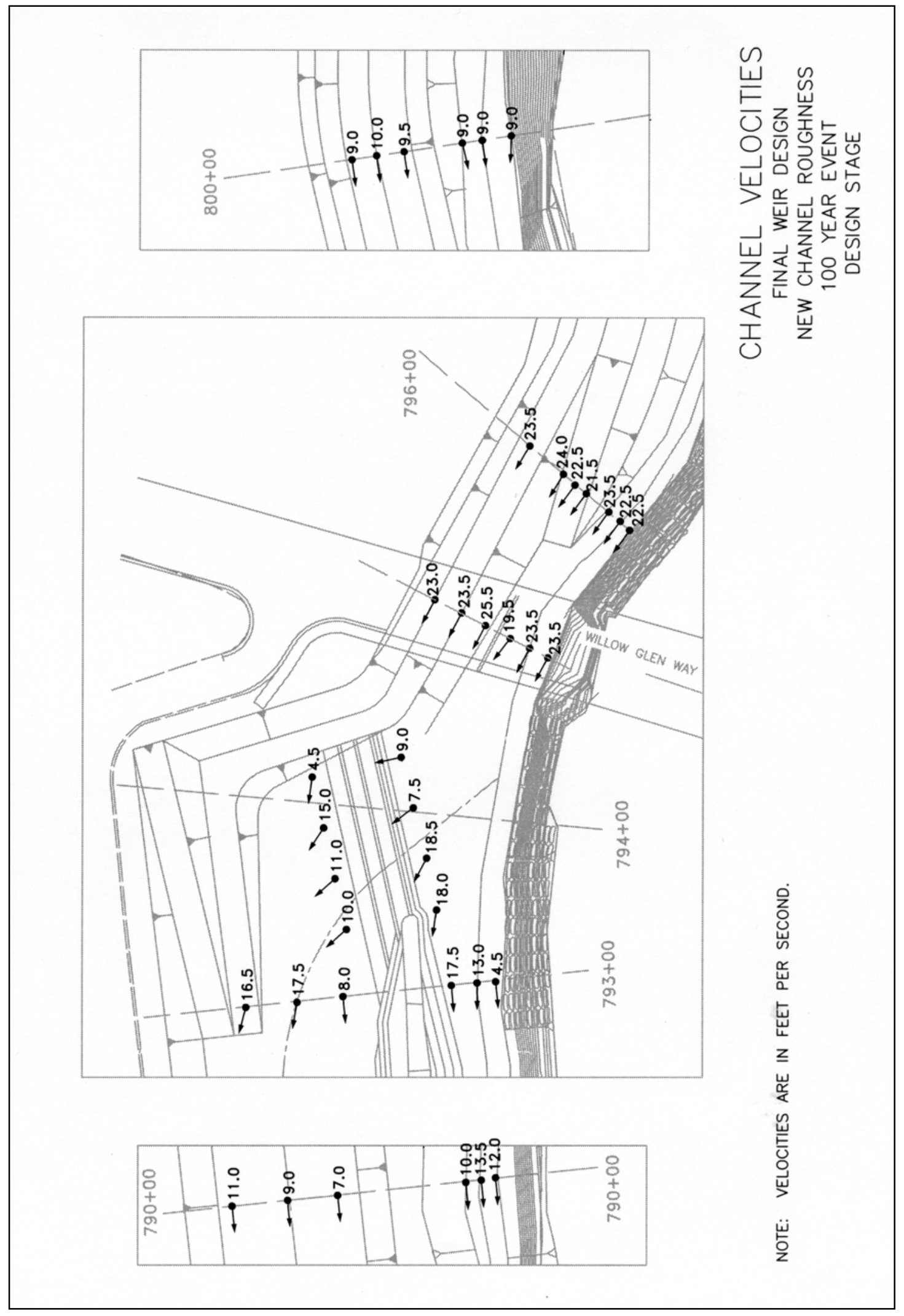

Plate 13 


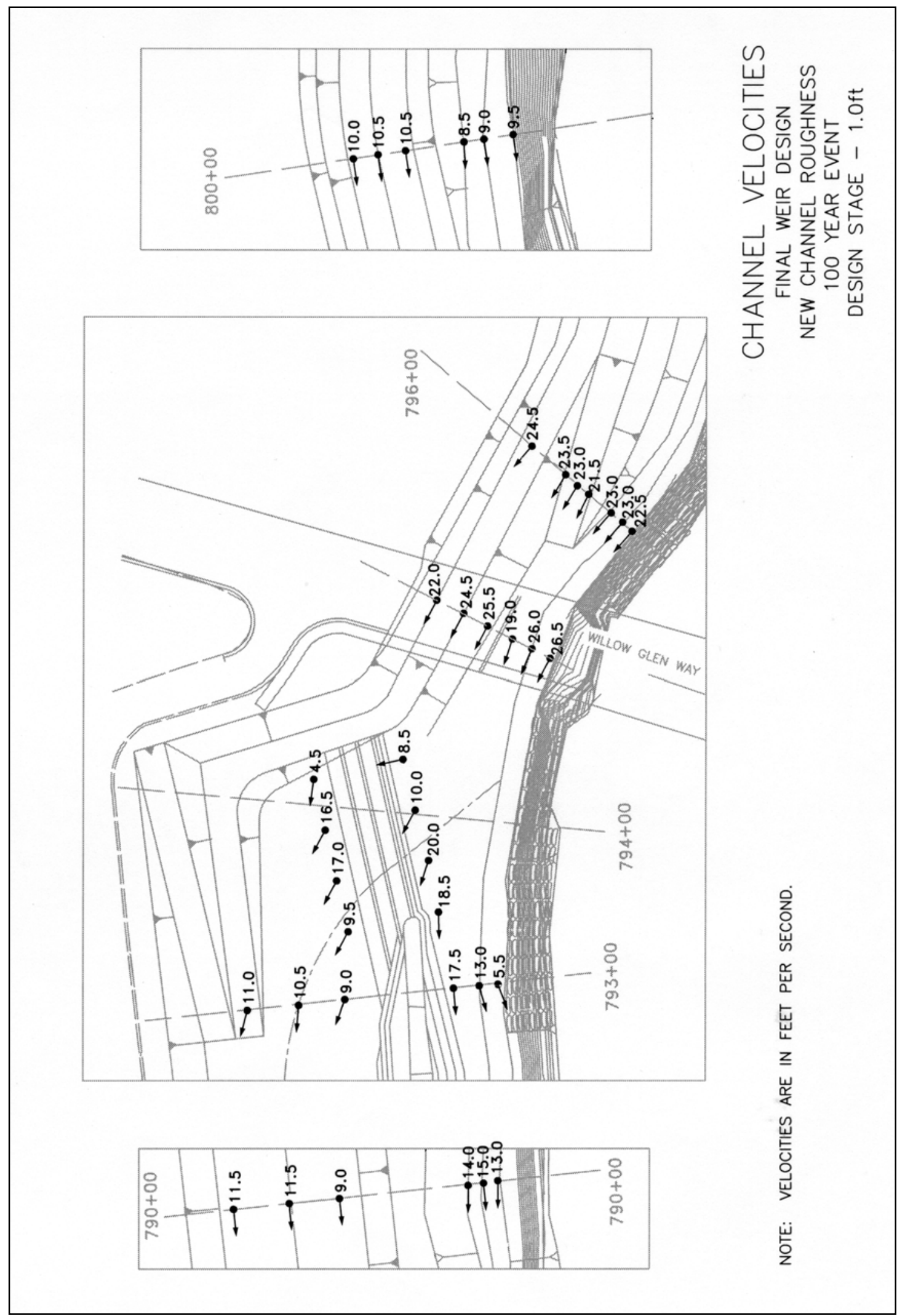

Plate 14 


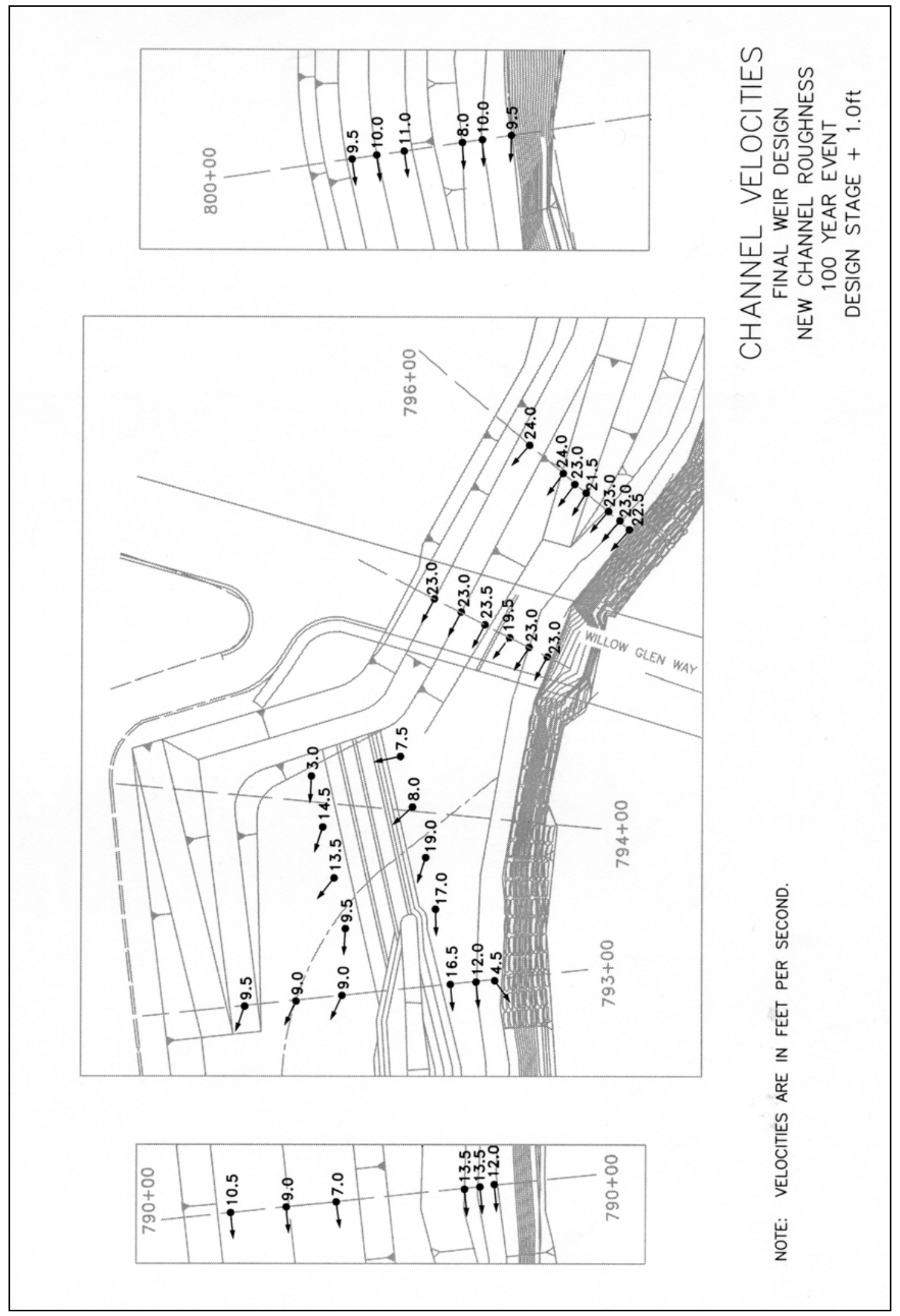

Plate 15 


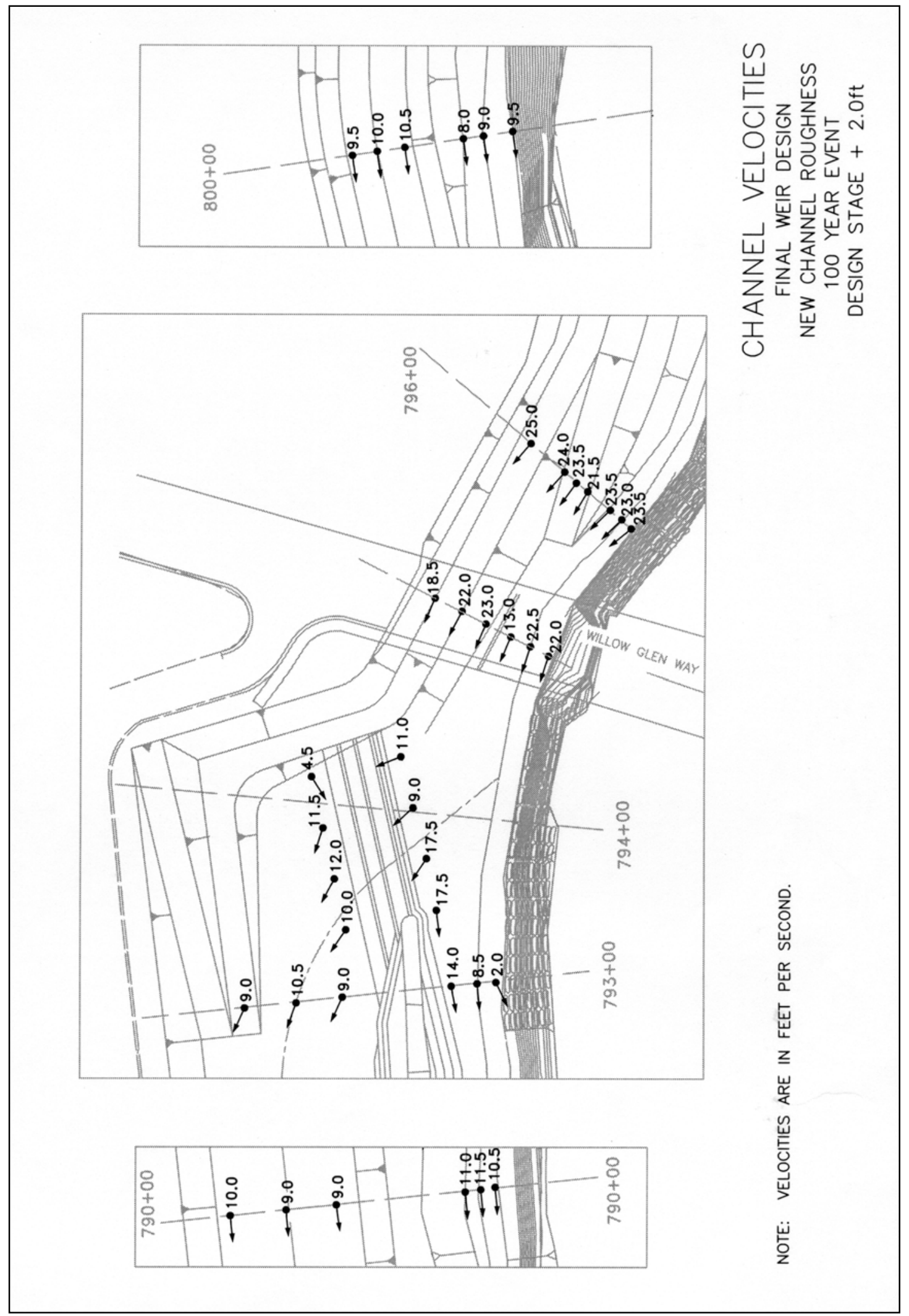

Plate 16 


\section{Appendix A Weir Coefficient Calculations}




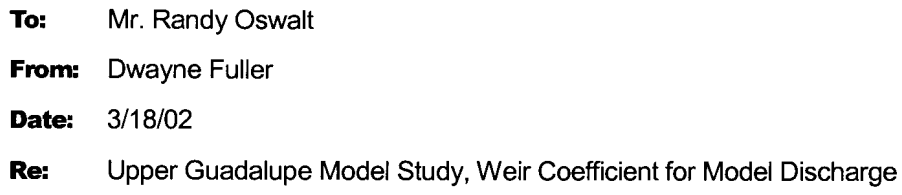

Randy,

This memo is intended to discuss the method used to set the discharge in the subject model. We are using two "horizontal sharp crest" weirs, one each downstream of the natural channel and the bypass channel. I used the discharge coefficient, $\mathrm{Ce}=3.2$, and assumed the $\mathrm{H} / \mathrm{P}$ was close enough to 0 to be negligible. These two values were used to set the weir sizes (see Figure 1) and used to measure the discharges in the model.

As a result of Dr. Wang questioning my selection of a discharge coefficient during our meeting and model demonstration earlier this week, I took another look at the discharge coefficient and $\mathrm{H} / \mathrm{P}$ ratio. I selected $\mathrm{Ce}$ values based on the head over the weir for both the natural and bypass channels for the four events used in the model evaluations. I used the method described in "Handbook of Hydraulics" written by Brater and King (see Figures 2-5).

For all seven discharge settings (four in the natural channel and three in the bypass channel) the discharge coefficient was 3.2 . 


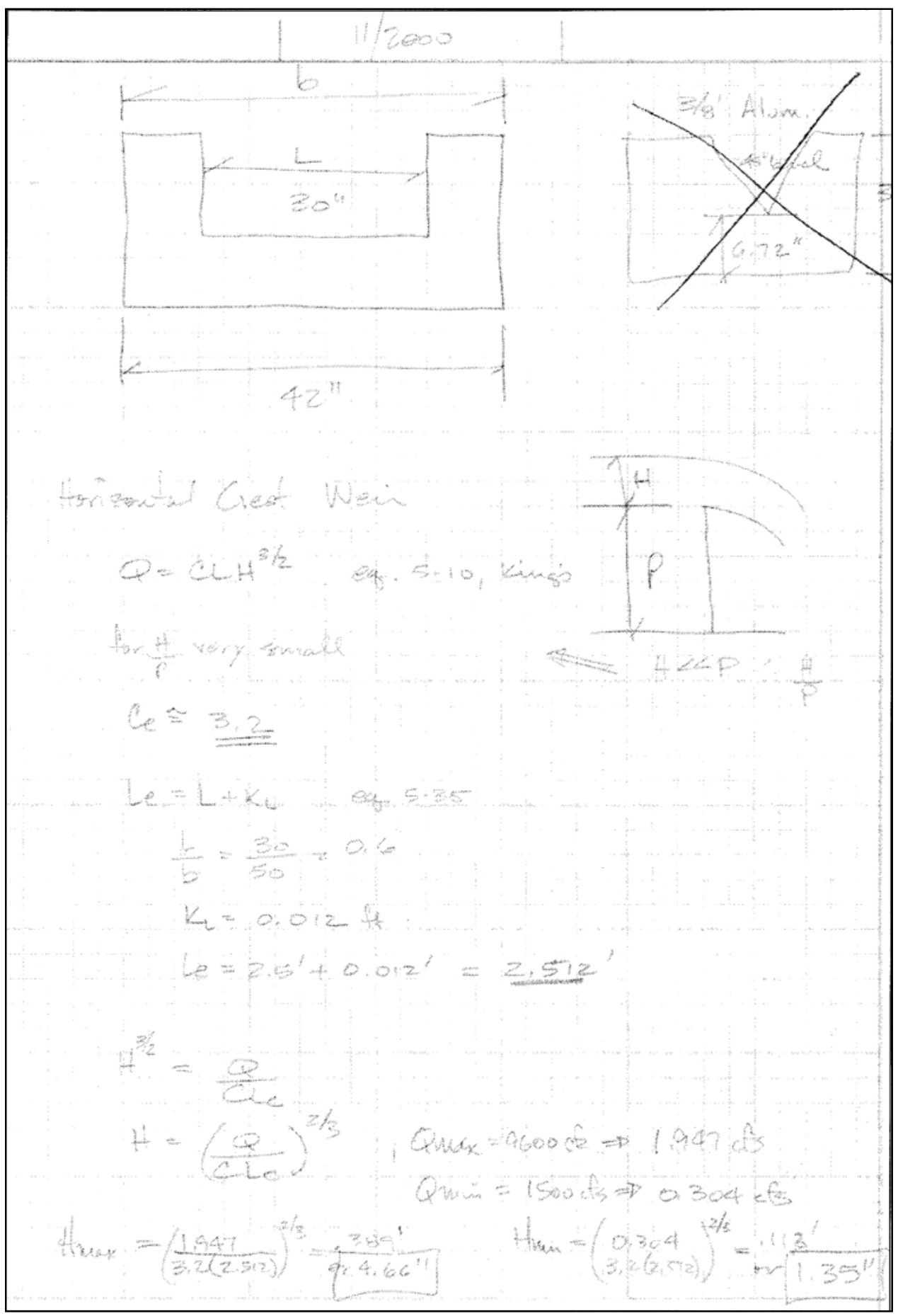

Figure A1. Weir coefficient calculations 


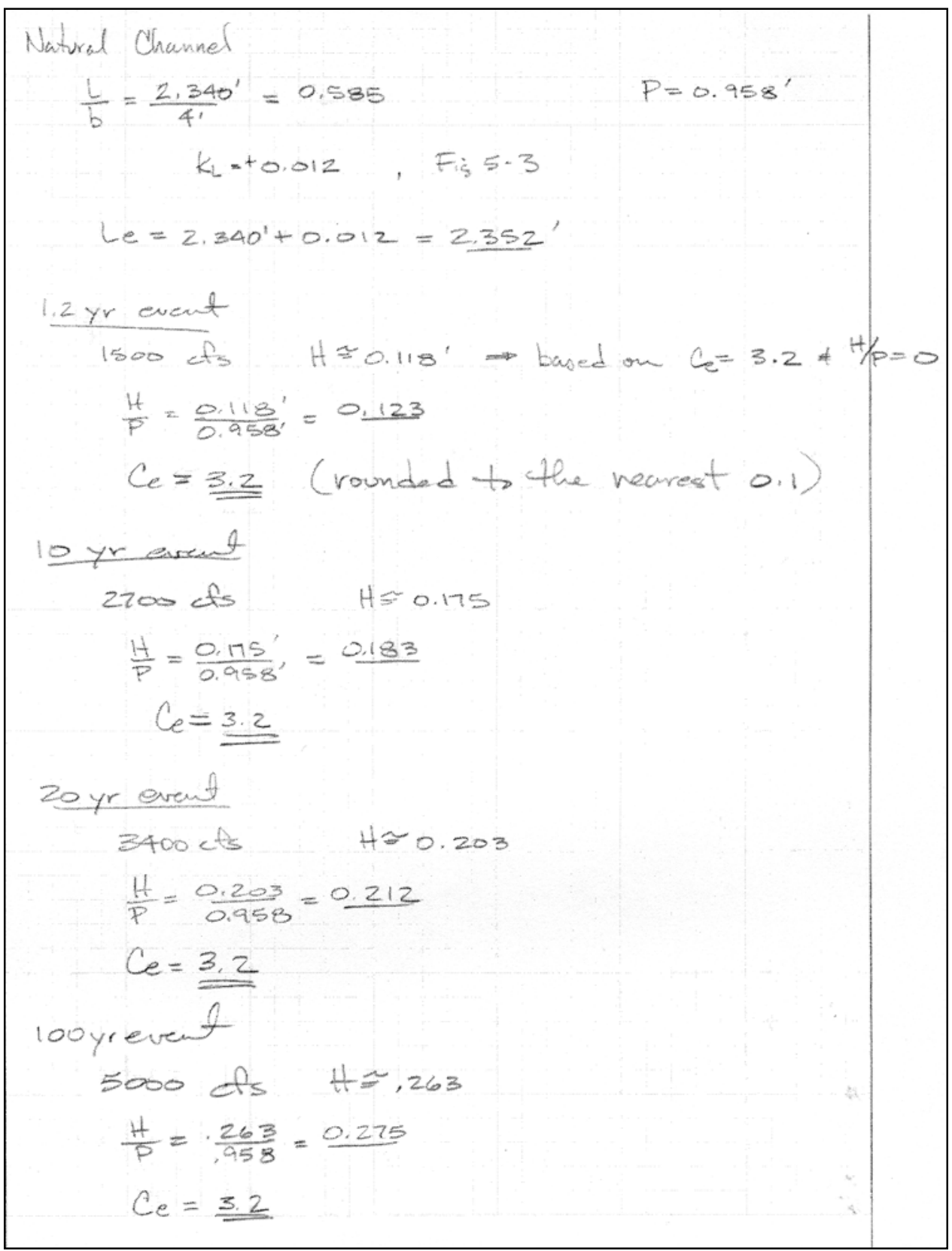

Figure A2. Weir coefficient calculations 


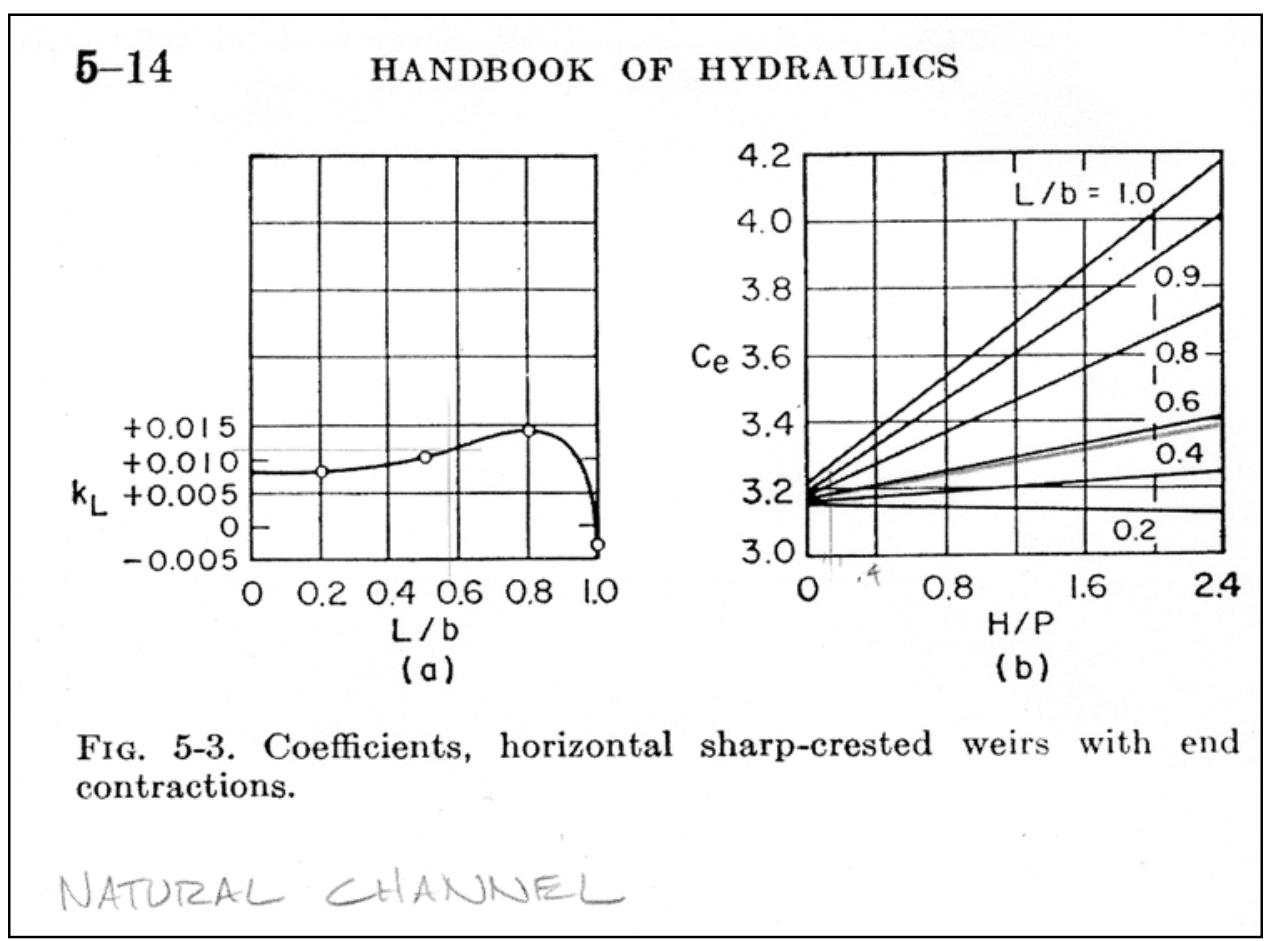

Figure A3. Graphs used in weir coefficient calculations 


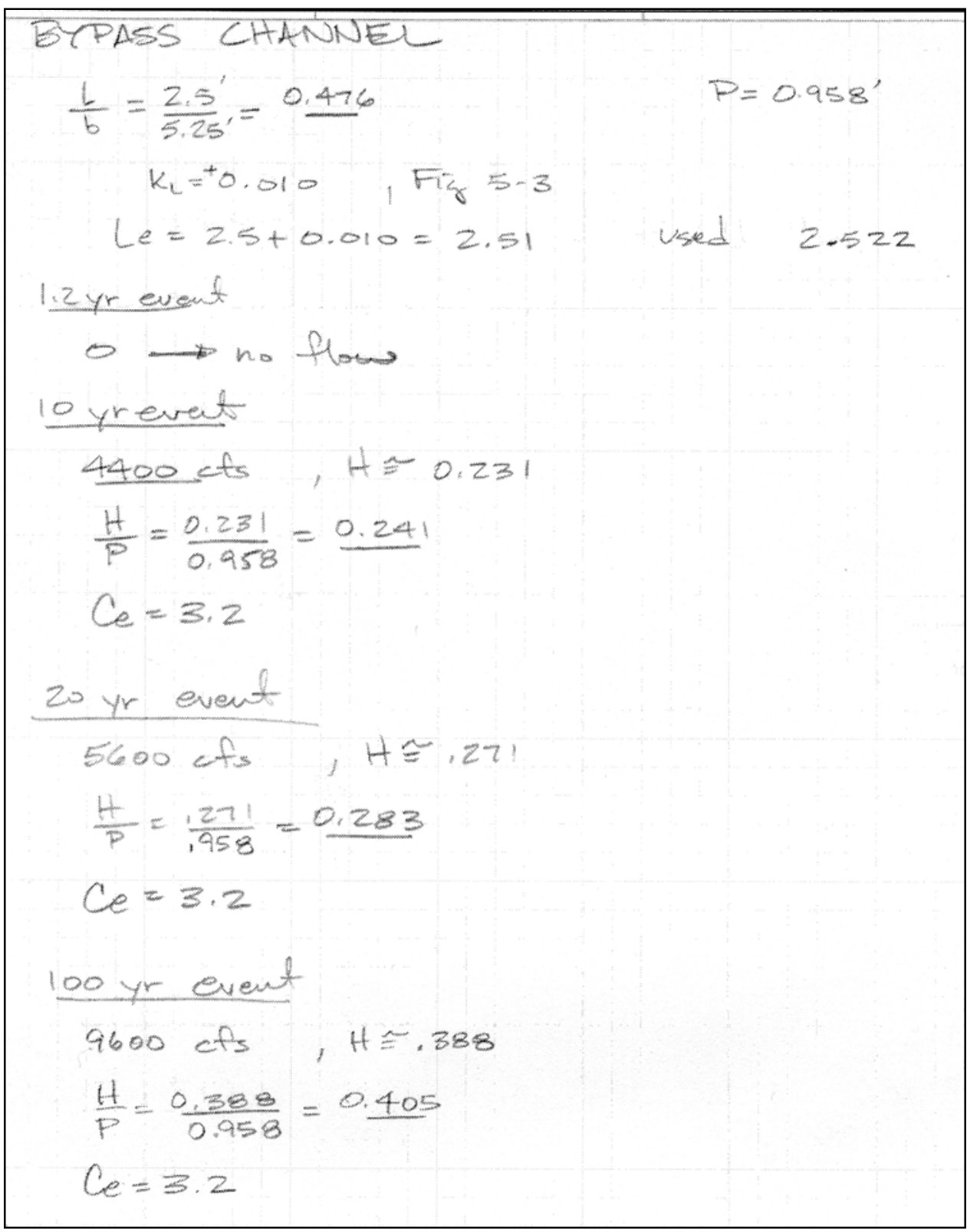

Figure A4. Weir coefficient calculations 


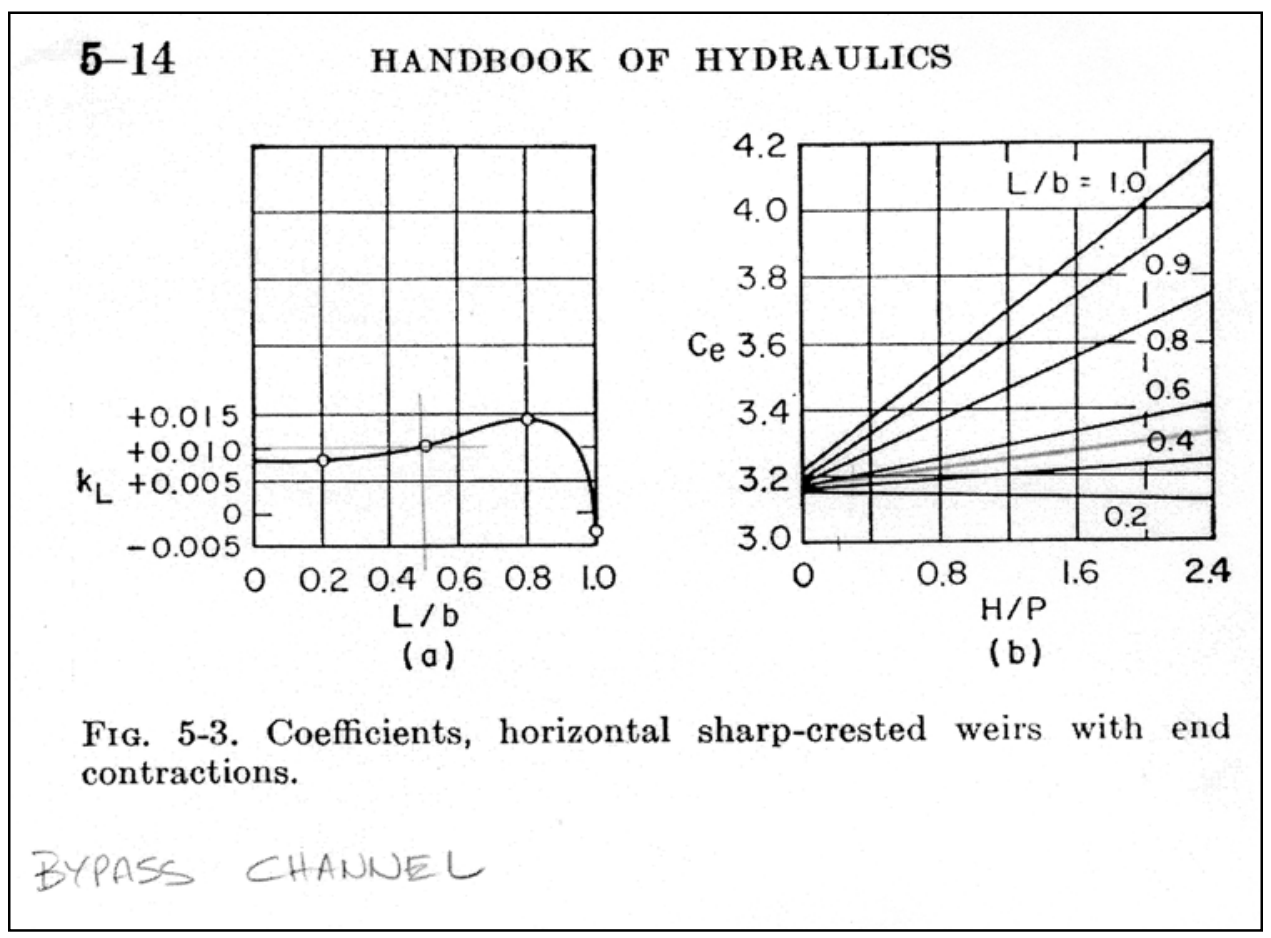

Figure A5. Graphs used in weir coefficient calculations 


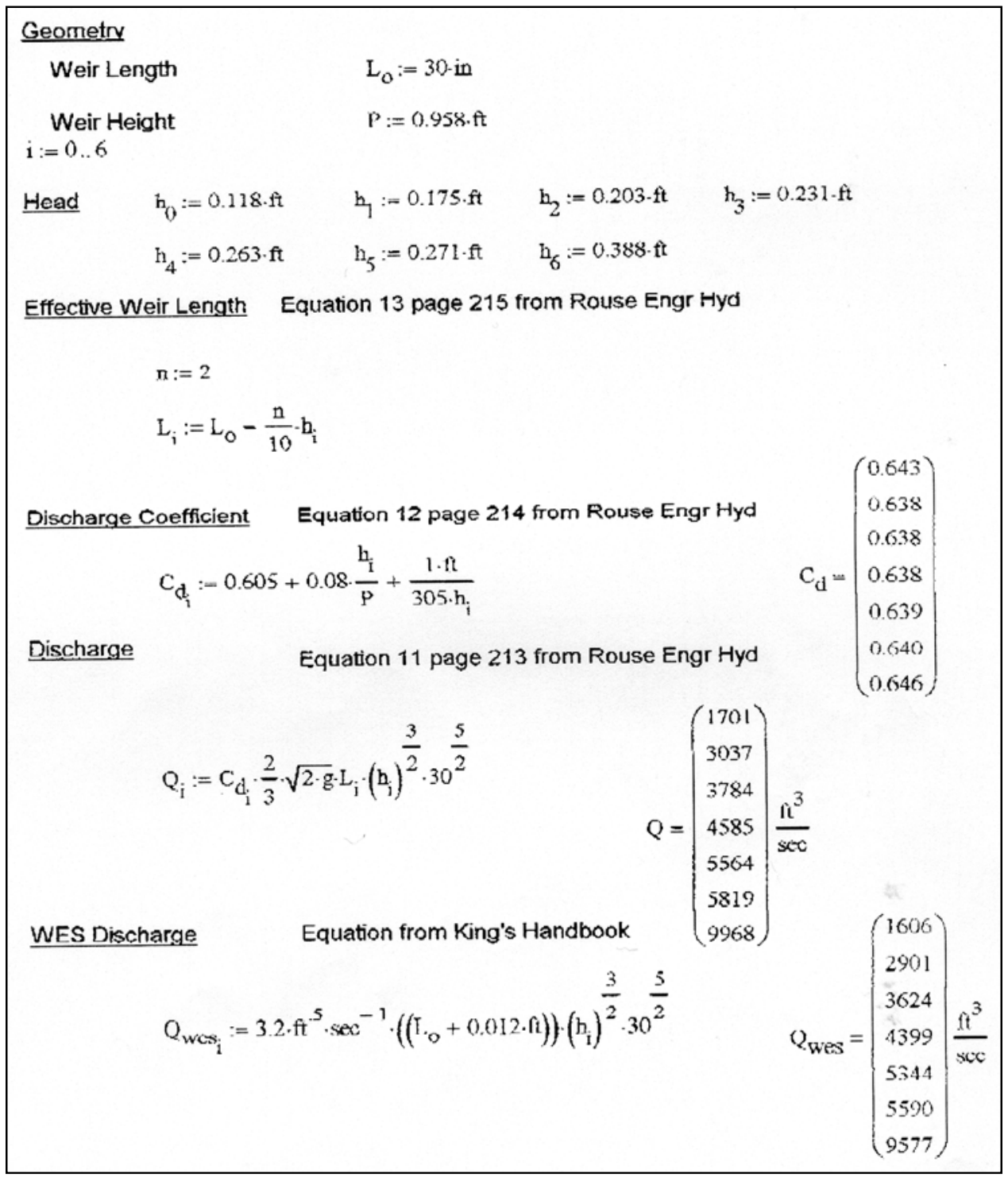

Figure A6. Upper Guadalupe weir calibration 


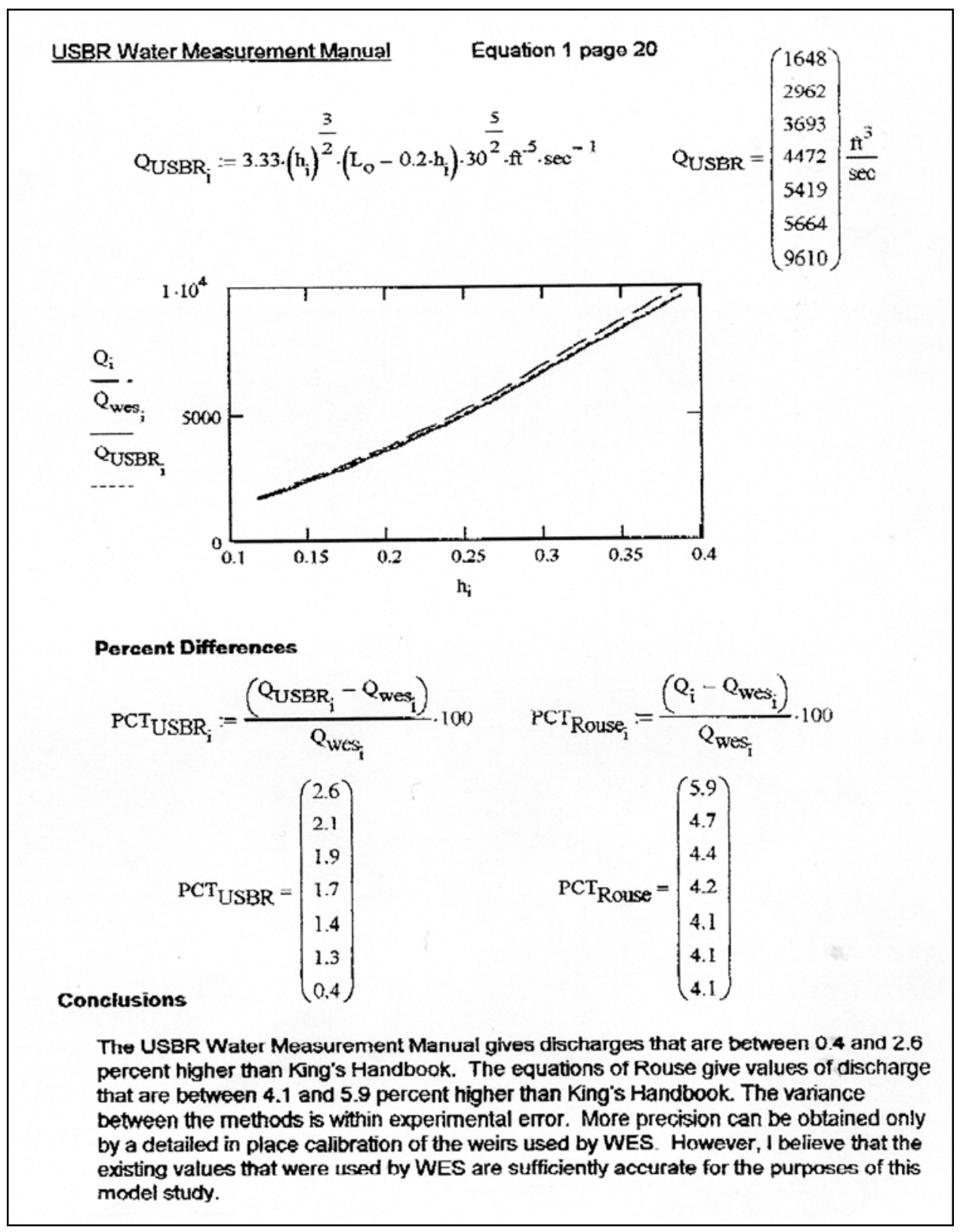

Figure A7. Upper Guadalupe weir calibration 